\title{
Current strategies for improving access and adherence to antiretroviral therapies in resource-limited settings
}

This article was published in the following Dove Press journal:

HIVIAIDS - Research and Palliative Care

4 January 2013

Number of times this article has been viewed

\author{
Michael L Scanlon ${ }^{1,2}$ \\ Rachel CVreeman ${ }^{1,2}$ \\ 'Department of Pediatrics, Indiana \\ University School of Medicine, \\ Indianapolis, IN, USA; ${ }^{2}$ USAID, \\ Academic Model Providing Access to \\ Healthcare (AMPATH) Partnership, \\ Eldoret, Kenya
}

\begin{abstract}
The rollout of antiretroviral therapy (ART) significantly reduced human immunodeficiency virus (HIV)-related morbidity and mortality, but good clinical outcomes depend on access and adherence to treatment. In resource-limited settings, where over $90 \%$ of the world's HIV-infected population resides, data on barriers to treatment are emerging that contribute to low rates of uptake in HIV testing, linkage to and retention in HIV care systems, and suboptimal adherence rates to therapy. A review of the literature reveals limited evidence to inform strategies to improve access and adherence with the majority of studies from sub-Saharan Africa. Data from observational studies and randomized controlled trials support home-based, mobile and antenatal care HIV testing, task-shifting from doctor-based to nurse-based and lower level provider care, and adherence support through education, counseling and mobile phone messaging services. Strategies with more limited evidence include targeted HIV testing for couples and family members of ART patients, decentralization of HIV care, including through home- and community-based ART programs, and adherence promotion through peer health workers, treatment supporters, and directly observed therapy. There is little evidence for improving access and adherence among vulnerable groups such as women, children and adolescents, and other high-risk populations and for addressing major barriers. Overall, studies are few in number and suffer from methodological issues. Recommendations for further research include health information technology, social-level factors like HIV stigma, and new research directions in cost-effectiveness, operations, and implementation. Findings from this review make a compelling case for more data to guide strategies to improve access and adherence to treatment in resource-limited settings.
\end{abstract}

Keywords: HIV, antiretroviral therapy, access, adherence, resource-limited settings

\section{Introduction}

In 2010, the World Health Organization (WHO) estimated there were 34 million people living with the human immunodeficiency virus (HIV). ${ }^{1}$ The emergence of antiretroviral therapy (ART) transformed HIV from a terminal illness to a chronic disease and resulted in significant decreases in HIV-related morbidity and mortality; ${ }^{2,3}$ however, good clinical outcomes depend on access and adherence to treatment. In low- and middle-income countries (LMIC), home to over $90 \%$ of the HIV-infected population, access to ART has dramatically expanded in the last decade, yet it is estimated that only $47 \%$ of adults and $23 \%$ of children who are eligible are accessing treatment. ${ }^{1}$ Recent studies suggest adults and children in resource-limited settings maintain or achieve better rates of adherence compared to those in resource-rich settings, ${ }^{4-6}$ but suboptimal adherence remains a threat for opportunistic infections, ${ }^{7}$ HIV disease progression, ${ }^{8-10}$ 
and viral resistance to ART. ${ }^{11-13}$ Evidence-based strategies to improve access and adherence in LMIC are critically needed. This paper reviews the current scientific literature on strategies to improve access and adherence to ART in LMIC. Important gaps in the literature are highlighted and future directions for research are proposed.

Access to ART requires successful passage through various stages of care, including diagnosis, linkage, disease-stage monitoring, and finally initiation of treatment. Following treatment initiation, good clinical outcomes require retention in care and high rates of adherence to therapy. ${ }^{14} \mathrm{~A}$ number of quantitative and qualitative studies reveal a myriad of barriers at all stages of access and adherence. While some barriers exist across settings, others act more frequently in resourcelimited settings. Reviews of barriers to access and adherence often conceptualize and organize barriers according to levels of action ${ }^{15-17}$ consistent with a social-ecological framework

Table I Barriers to access and adherence to antiretroviral therapy in low- and middle-income countries

\begin{tabular}{|c|c|}
\hline Level of action & Barriers \\
\hline \multirow[t]{12}{*}{ Intrapersonal } & Knowledge of serostatus and treatment options ${ }^{200-204, * *}$ \\
\hline & Difficulty understanding/managing \\
\hline & treatment, ${ }^{108,116,1117,120,205-207, * *}$ complicated \\
\hline & regimens, ${ }^{\mid 16,207-213}$ ART side effects ${ }^{|17,208-210,2| 2-218}$ \\
\hline & Simply forgetting to come to clinic or take \\
\hline & medicines, ${ }^{205,207,208,213-215,219}$ falling asleep ${ }^{210,214,219}$ \\
\hline & Emotional distress (eg, depression), ${ }^{108,214,217,220}$ \\
\hline & substance addiction $^{205,213,221,222}$ \\
\hline & Perceptions of health, ${ }^{206,213,214,223,224}$ \\
\hline & treatment, ${ }^{205,217,225,226}$ and alternative/traditional \\
\hline & medicines $^{227-229}$ \\
\hline & Available financial resources, ${ }^{230,231, *}$ food insecurity ${ }^{232-234}$ \\
\hline \multirow{12}{*}{$\begin{array}{l}\text { Interpersonal/ } \\
\text { social }\end{array}$} & Lack of family or social support, ${ }^{180,235,236}$ dependency \\
\hline & on partners for financial resources ${ }^{201,237, *}$ or \\
\hline & permission for treatment ${ }^{106, *}$ \\
\hline & Household conflict, ${ }^{108,116,216, * *}$ Low parental \\
\hline & education level ${ }^{117, * *}$ \\
\hline & Fear of violence and/or abandonment $202,238, *$ \\
\hline & Lack of disclosure of own* or child's \\
\hline & status $^{108,120,207,211-214,216,217,220,239,240, * *}$ \\
\hline & Negative perception of providers ${ }^{206,241}$ and poor \\
\hline & patient-provider communication ${ }^{242,243}$ \\
\hline & Lack of community involvement in ART programs ${ }^{16,201}$ \\
\hline & Stigma and discrimination ${ }^{108,207,216,220,239, *}$ \\
\hline \multirow[t]{7}{*}{ System } & Costs of care and treatment, ${ }^{205,208,213,215,244,245}$ distance \\
\hline & to clinic $^{205,2|2,2| 3,2|9,246-25|}$ \\
\hline & $\begin{array}{l}\text { Lack of integration/coordination with other health } \\
\text { services }^{252,253}\end{array}$ \\
\hline & Drug shortages and stock-outs $218,254,255$ \\
\hline & Long waiting times at clinics $229,234,256$ \\
\hline & Inadequate laboratory infrastructure/resources ${ }^{257}$ \\
\hline & Confidentiality of services ${ }^{258}$ \\
\hline
\end{tabular}

Notes: *Significant barrier for women; **significant barrier for children and adolescents. discussed elsewhere. ${ }^{18,19}$ Table 1 summarizes commonly cited barriers to access and adherence in LMIC at the levels of intrapersonal, interpersonal/social, and system. Barriers more common to those living in resource-limited settings may include lack of knowledge of HIV status and treatment options, fear of stigma and discrimination, and system-level barriers, sometimes referred to as structural barriers, ${ }^{20}$ that constrain individual and community-level efficacy to access and adhere to treatment through poor health care infrastructure and resources. Factors such as entrenched poverty and inequality operate at all levels and may especially affect treatment opportunities for women and children. Improving access and adherence to ART will require interventions that address barriers at each level of action while also considering how these barriers operate at the multiple stages of treatment, across different contexts, and among diverse populations.

\section{Evidence-based strategies}

A review of the literature reveals limited empirical data to guide strategies to improve access and adherence to ART (Table 2). Few randomized, controlled trials (RCTs), widely considered the gold standard in scientific rigor and methodology, ${ }^{21,22}$ evaluate interventions in LMIC and strategies often rely on small case and observational studies. The most compelling data from well-designed observational studies and RCTs conducted in LMIC are reviewed here according to three stages of treatment: HIV testing and diagnosis; linkage to and retention in care; and adherence to ART.

\section{HIV testing and diagnosis}

As availability of ART in resource-limited settings expands, voluntary counseling and testing (VCT) services act as critical gateways to testing, early diagnosis and treatment. ${ }^{23}$ Despite massive scale-ups in national HIV testing programs, ${ }^{24,25}$ studies suggest that up to $80 \%$ of HIV-infected adults do not know their status in some sub-Saharan African settings, ${ }^{26,27}$ although rates of testing vary substantially by country. A national survey in Lesotho found that the percentage of women who had been tested for HIV in the past 12 months had increased from $6.3 \%$ in 2004 to $42 \%$ in 2009 , while a similar national survey in the Congo only showed rates of testing increasing from $3.2 \%$ in 2004 to $6.5 \%$ in $2009 .{ }^{1}$

Low uptake in testing and barriers to accessing traditional, client-initiated VCT services have led to new approaches in HIV testing, including provider-initiated, home-based and mobile or community testing. ${ }^{28}$ Routine "opt-out" testing by providers, which is now recommended by the WHO as part of standard medical care in certain settings, ${ }^{29}$ is reported to 
Table 2 Evidence base for strategies to improve access and adherence in LMIC

\begin{tabular}{|c|c|c|c|}
\hline \multirow[t]{2}{*}{ Level of support } & \multicolumn{3}{|l|}{ Stage of care } \\
\hline & Testing and diagnosis & Linkage to and retention in care & Adherence \\
\hline $\begin{array}{l}\text { Limited or weak } \\
\text { evidence }\end{array}$ & 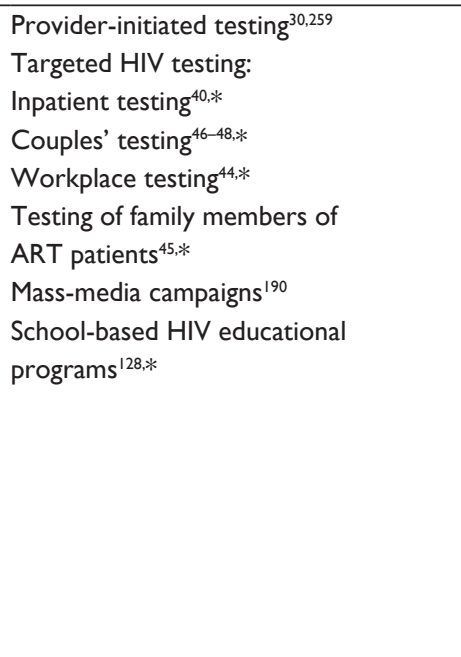 & $\begin{array}{l}\text { Referral programs (referral forms, } \\
\text { transport stipends, patient navigators); }{ }^{57} \\
\text { patient navigators } \\
\text { Point-of-care CD4 testing; }{ }^{60-62,64} \\
\text { pre-ART prophylaxis }{ }^{260} \\
\text { Free services; }{ }^{261} \text { cash transfers for } \\
\text { transportation to clinic; ; } * \text { food-assistance } \\
\text { programs }^{262} \\
\text { Home-based ART program; } 80, * \\
\text { community group-based ART program }^{182} \\
\text { Patient-centered care (ex-child-friendly } \\
\text { clinics, }{ }^{129} \text { family-based care } \\
\text { Health information systems } \\
\text { (ie, electronic medical records) } \\
\text { Decentralization of HIV services }{ }^{70-72} \\
\text { and integration into primary care, TB, } \\
\text { antenatal services } \\
\text { a2-74,76 }\end{array}$ & $\begin{array}{l}\text { Adherence support through peer } \\
\text { health workers } \\
\text { supporters and treatment } \\
\text { Peer-delivered DOT-ART } \\
\text { and nurse-delivered DOT-ART } \\
\text { Targeted DOT-ART for HIV-TB } \\
\text { patients }{ }^{941-143} \text { and children } \\
\text { Adherence counseling with } \\
\text { EDM }^{87, *} \\
\text { Disclosure of HIV status to } \\
\text { children }^{133} \\
\text { Food-assistance programs } \\
\end{array}$ \\
\hline Strongest evidence & $\begin{array}{l}\text { Non-standard approaches to VCT: } \\
\text { Home-based testing } \\
\text { Mobile or community-based } \\
\text { testing }{ }^{24,35,38,42,42,109, \dagger} \\
\text { Testing in antenatal care settings } \\
{ }^{111-113, \dagger}\end{array}$ & $\begin{array}{l}\text { Task-shifting to nurse-based, } \\
\text { PHW care }{ }^{66-69,78,79,81,265, \dagger}\end{array}$ & $\begin{array}{l}\text { Adherence counseling/ } \\
\text { education } \\
\text { Mob,86,266, } \\
\text { Mobile phone SMS }\end{array}$ \\
\hline
\end{tabular}

Notes: *Evidence from RCTs; †evidence from RCTs and observational studies.

Abbreviations: DOT-ART, directly observed antiretroviral therapy; HIV, human immunodeficiency virus; PHW, peer health worker; SMS, short message services; RCT, randomized controlled trial; VCT, voluntary counseling and testing; TB, tuberculosis.

increase early diagnosis and access to treatment, ${ }^{30}$ especially within antenatal care settings. ${ }^{31}$ A number of observational studies show promising early results in increased testing uptake with home-based ${ }^{32-34}$ and mobile ${ }^{24,35}$ services. A large cohort study in rural Uganda found that 1 year after offering home-based testing services, receipt of HIV tests increased more than 5 times compared to previous clinic-based testing. ${ }^{36}$ Studies assessing the cost-effectiveness and feasibility of home- and mobile-based testing in resource-limited settings have begun to emerge, ${ }^{37-39}$ but more research is needed.

There are few RCTs evaluating interventions to increase uptake of HIV testing in LMIC. An RCT investigating inpatient testing found that patients in an urban hospital in Uganda were significantly more likely to receive testing if it was offered during their hospital stay (intervention $=98.8 \%$ ) compared to patients who were offered referral cards and travel reimbursement for testing one week after discharge (control $=68.7 \%) .{ }^{40} \mathrm{~A}$ randomized population-based study in Zambia found that individuals in the intervention group who were offered VCT at a location of their choice $(84 \%$ chose home-based VCT) were 4.7 times more likely to be tested than individuals in the control who were offered VCT at the local health clinic. ${ }^{41}$ In the largest RCT to date,
Sweat et al reported on Project Accept, a community-based intervention among communities in Tanzania, Thailand and Zimbabwe. ${ }^{42}$ Intervention components included community mobilization through HIV working groups and outreach coordinators, mobile VCT in community centers and other public places, and post-test support services. ${ }^{43} \mathrm{~A}$ mean difference of $40.2 \%$ (95\% confidence interval [CI]: 15.8-64.7) was reported in the proportion of patients receiving HIV testing in intervention versus control communities, plus intervention communities had more first-time testers compared to controls (Tanzania, 37\% vs 9\%; Thailand, 69\% vs 23\%; Zimbabwe, $51 \%$ vs $5 \%) .{ }^{42}$ RCTs investigating on-site testing at occupational health clinics, ${ }^{44}$ and home-based testing offered to family members of ART patients ${ }^{45}$ also found significantly increased testing rates compared with controls. RCTs using antenatal care settings to encourage couples counseling and testing of sexual partners have revealed mixed success. ${ }^{46-48}$

\section{Linkage to and retention in HIV care}

The potential benefits of early HIV diagnosis through increased uptake in counseling and testing rely on effective linkage to and retention in HIV care systems. There is growing evidence that individuals testing positive are not 
effectively linked to HIV care programs, leading to late presentation for treatment and increased risks of HIV-related morbidity and mortality. ${ }^{49-51}$ Recent studies suggest between $30 \%-62 \%$ of individuals who test positive are linked to care in resource-limited settings. ${ }^{40,52-54}$ Data on retention in care is also concerning. A review of data from 15 large-scale HIV treatment programs in LMIC revealed an average of $21 \%$ of patients were lost to follow-up by 6 months and 4\% were lost after receiving their first ART prescription. ${ }^{55}$ In South Africa, home to over $17 \%$ of the world's HIV-infected population, losses to follow-up have actually been increasing in recent years, ${ }^{56}$ a possible indicator of the burden placed on under-resourced health care systems as more individuals access treatment.

Strategies to improve linkages and retention are emerging, although many studies suffer from weak study design and small sample sizes. In a case study in rural Tanzania, introduction of simple referral forms, along with transportation stipends and community navigators, showed success in increasing and monitoring linkages to care. ${ }^{57} \mathrm{~A}$ cross-sectional study in Kenya supported mobile testing alongside patient navigators to improve linkage. ${ }^{58}$ Utilization of point-of-care CD4 count technology is being evaluated to enhance CD4 monitoring, improve referral services for timely initiation of ART and decrease loss to follow-up. ${ }^{59-63}$ In a cohort study in Mozambique, implementation of point-of-care CD4 testing at primary health centers resulted in a decrease in loss to follow-up before completion of CD4 staging (from 57\% to $21 \%$ ), decrease in loss to follow-up before treatment initiation (from 64\% to $33 \%$ ) and an increase in enrolled patients initiating ART (from 12\% to $22 \%) .{ }^{64}$ In accordance with global guidelines for HIV care in LMIC, ${ }^{65} \mathrm{HIV}$ care systems are implementing various systemlevel changes to improve linkage and retention. Observational studies generally report positive impacts on linkage, retention and overall treatment outcomes with task-shifting from doctor-based to nurse-based care, ${ }^{66-69}$ decentralization of HIV services from higher level facilities to satellite clinics, ${ }^{70-72}$ and integration of HIV care into tuberculosis (TB), antenatal and other primary care services. ${ }^{73,74}$ Other studies highlight the need for careful implementation in the transition of these services to ensure personnel are trained properly and resources are available. $^{75,76}$

Evidence from RCTs evaluating linkage to and retention in HIV care is limited. A randomized trial in Uganda found that inpatient HIV testing resulted in only $56 \%$ of patients enrolling in HIV care, actually lower than the control group that was offered referral to outpatient testing. ${ }^{40}$ An RCT in rural Uganda found that cash transfers (approximately
US\$5-\$8 per patient per month) for transportation to clinic appointments significantly decreased loss to follow-up $(P=0.04)$ among the intervention group, although sample size was small. ${ }^{77}$ Supporting the efficacy of task-shifting to nurse-managed care, a randomized non-inferiority trial in Uganda found that a nurse-peer model achieved comparable rates of adherence, viral load, and CD4 counts compared to standard clinician-based care. ${ }^{78}$ An RCT in South Africa found nurse-based care to be equivalent to doctor-managed care in treatment failure and retention in care, with hazard ratios of 1.09 (95\% CI: $0.89-1.33)$ and 1.13 (95\% CI: 0.81-1.59), respectively. ${ }^{79}$ A cluster-randomized trial found that home-based HIV care through trained lay workers who supported drug delivery and monitored clinical status and adherence in patients was as effective as standard clinicbased care in Uganda in achieving equivalence in its primary endpoint, viral failure (relative risk [RR] 1.04, 95\% CI: 0.78-1.40), and in secondary endpoints, mortality (RR 0.95, 95\% CI: $0.71-1.28$ ) and proportion of patients who reported $100 \%$ adherence (94\% in home-based intervention group versus $91 \%$ in standard care group). ${ }^{80}$ While the study reported no significant difference in loss to follow-up, home-based ART reduced overall HIV care costs incurred by patients by $50 \%$ in the first year and by $66 \%$ in subsequent years compared to clinic-based care. An RCT in Kenya found that an intervention using trained HIV-infected individuals as community care coordinators delivering monthly home assessments with clinic visits every 3 months resulted in similar clinical outcomes, including viral load, CD4 count and risk of opportunistic infections, compared to a control group with monthly clinic visits. ${ }^{81}$

\section{Adherence to ART}

A recent meta-analysis of adherence rates found $77 \%$ of adults achieved adequate adherence in sub-Saharan Africa compared to $55 \%$ in North America ${ }^{6}$ but rates vary significantly by setting. The literature on adherence interventions is relatively broad. Major reviews of adherence interventions, conducted mostly in resource-rich settings, reveal that the most effective are typically patient-based, behavioral interventions designed to build patient knowledge and efficacy through practical medication management skills. ${ }^{82-84}$ While the evidence base from resource-limited settings is much more limited, it is still significantly wider than for testing, linkage, and retention interventions and provides several RCTs for evaluation.

A number of patient-based counseling and education interventions have been evaluated in LMIC, and some show 
positive impacts on adherence. ${ }^{85,86}$ Individual adherence counseling at ART initiation reduced the risk of poor adherence $(P=0.055)$ and viral failure $(P=0.01)$ at 18 months follow-up compared to controls in an RCT in Kenya, although only reduced risk of viral failure was statistically significant. ${ }^{86}$ A small RCT in China found that using feedback from electronic dose monitoring (EDM) during counseling led to significant increases in mean adherence rates $(P=0.003)$ but not mean CD4 counts $(P=0.07)$ at 12 -month followup compared to controls who received counseling only. ${ }^{87}$ Busari et al investigated the effect of a structured teaching method compared to standard clinic care among 620 ART patients in Nigeria ${ }^{85}$ Intervention group members received education in 10 modules including benefits of treatment, adverse drug effects, self-efficacy, and social support. At 8 months follow-up, the intervention group achieved significantly higher rates of adherence $(P<0.001)$, CD4 counts $(P<0.001)$, decreased frequency of opportunistic infections $(P=0.002)$, and lower mortality $(P=0.008)$. Two Brazilian RCTs investigating interventions delivered by social workers showed no effectiveness in improving adherence or biological markers. ${ }^{88,89}$ One study used social workers to deliver motivational interviews and counseling through home visits ${ }^{89}$ while the other study compared the effect of small educational workshops versus group video sessions. ${ }^{88}$ Supplementing counseling and education with material support to address poverty-related barriers needs further investigation. Cohort studies in Zambia ${ }^{90}$ and Nigeria ${ }^{91}$ support the use of food assistance for improving adherence among food-insecure patients.

Several RCTs have investigated the use of peer health workers, treatment supporters and directly observed therapy (DOT-ART), with mixed results. An RCT in Uganda using peer health workers to deliver clinic- and biweekly homebased adherence counseling and social support did not find significant improvements in adherence over controls, but did show significant decreases in the risk of viral failure after 96 weeks (RR 0.50, 95\% CI: 0.44-1.49) until end of follow up at 192 weeks (RR 0.07, 95\% CI: $0.006-0.71$ ). ${ }^{92} \mathrm{~A}$ mixedmethods evaluation of the intervention found that the use of peer health workers improved access to care, care delivery, and patient-provider communication. ${ }^{93}$ In another RCT in Uganda, use of a patient-nominated treatment supporter, a family member, friend, or neighbor educated on HIV and who agreed to attend counseling and clinic sessions with the patient, did not significantly increase adherence or clinic attendance against a standard adherence support program. ${ }^{94}$ A study in Tanzania evaluated the impact of a treatment supporter alongside standard adherence counseling and found no significant differences in adherence or mean CD4 counts compared to controls. ${ }^{95}$ A clinic-based, once-daily DOT-ART intervention delivered by trained peers in Mozambique found mean adherence rates and CD4 counts at 6 and 12 months follow up did not increase significantly compared to controls although achieving $>90 \%$ adherence was significantly more likely for the intervention arm at 6 months (odds ratio [OR] 2.0,95\% CI: $0.93-4.5) .{ }^{96}$ RCTs in Nigeria ${ }^{97}$ and South Africa ${ }^{98}$ using patient-nominated DOT-ART treatment supporters and one in Kenya ${ }^{99}$ using nurse-based DOT-ART revealed initial improvements in adherence, but failed to demonstrate significant increases in adherence, CD4 counts, and viral suppression at study endpoints.

While limited in number, studies assessing interventions using mobile phones have shown positive results. Two RCTs in Kenya investigated the use of mobile phone short message service (SMS) in improving adherence. ${ }^{100,101}$ Pop-Eleches et al found that an intervention group receiving weekly SMS reminders to take ART were significantly more likely to achieve $>90 \%$ adherence rates $(P=0.03)$ and less likely to experience treatment interruptions $(P=0.03)$ at 48 weeks' follow-up compared to controls. ${ }^{101}$ Lester et al found significant improvements in adherence $(P=0.006)$ and viral suppression $(P=0.04)$ among an intervention group that received weekly interactive SMS (inquiring about health and well-being), with follow-up calls for nonrespondents after 48 hours. ${ }^{100}$ Another RCT in Pakistan found that weekly phone reminders significantly improved adherence and decreased viral load, although sample size and length of follow-up were significantly less than the studies in Kenya. ${ }^{102}$ In an RCT in Uganda discussed previously investigating the impact of peer health workers, ${ }^{92}$ a substudy evaluated a mobile phone intervention whereby health workers called and text messaged higher-level providers with patient-specific clinical information and adherence data. ${ }^{103}$ While the intervention did not find significant improvements in adherence, biological markers or loss to follow-up in patients randomized to health workers in the intervention arm, a mixedmethods evaluation revealed mobile phones improved care delivery and was widely believed by patients, clinic staff, and peer health workers to improve clinical care. Two RCTs investigating the impact of SMS on adherence to ART are ongoing in Cameroon ${ }^{104}$ and India. ${ }^{105}$

\section{Special populations}

There are a number of populations that face higher burdens of HIV, worse clinical outcomes and additional and/ 
or unique barriers in accessing and adhering to ART. These populations require particular consideration, especially in LMIC where they may be further marginalized and isolated from HIV care.

\section{Women}

In LMIC in 2010, women represented $51 \%$ of those still requiring treatment and $58 \%$ of those currently on ART. ${ }^{1}$ It is estimated that coverage - the percentage of individuals needing treatment who are receiving it - among women is higher than men, especially in Asia and sub-Saharan Africa, while coverage rates for women in Latin America are slightly lower. Young women face an especially high burden of HIV in sub-Saharan Africa, where women make up $71 \%$ of HIV-positive young adults aged 15-24 years old. ${ }^{1}$ Preventing mother-to-child transmission, which is the route of infection in $90 \%$ of HIV-positive children in LMIC, hinges on expanding access and adherence to ART among pregnant mothers. In 2010, only $35 \%$ of pregnant women in LMIC received an HIV test and $48 \%$ of HIV-infected pregnant women accessed ART regimens as recommended by the WHO to prevent vertical transmission. ${ }^{1}$ Women in many settings face additional barriers to access and adherence to treatment. Qualitative studies suggest important sex-based barriers may dissuade women from accessing and adhering to HIV treatment, including requiring a male partner's permission to seek testing and treatment services. ${ }^{106}$ Women in some settings fear disclosing their HIV status to their partner because of potential negative consequences of emotional or physical abuse ${ }^{107}$ or forcible displacement from their homes. ${ }^{108}$ In many LMIC, women are particularly vulnerable to poverty and socioeconomic inequalities that create additional barriers to access and adherence such as low levels of education, social status, and financial resources.

Few studies in LMIC evaluate interventions aimed specifically at improving women's access and adherence to HIV care. Qualitative studies of home-based and mobile VCT services reveal that these approaches may be more available to women as they do not require travel to clinic or permission and/or money from partners. ${ }^{109,110}$ Provider-initiated counseling and testing for women in antenatal care settings has been shown to be well-accepted and to significantly increase testing uptake and participation in prevention of mother-tochild transmission care. ${ }^{111,112}$ A cluster RCT in Zambia found that counseling and testing services in hospital labor wards increased the number of women on ART during birth and improved adherence. ${ }^{113}$

\section{Children and adolescents}

In 2010, there were an estimated 3.4 million children under 15 years living with HIV. Adolescents represent one of the fastest-growing HIV-infected populations in the world. Young people aged $15-24$ years now make up $41 \%$ of new HIV infections in persons older than 15 years. ${ }^{114}$ Children and adolescents in resource-limited settings bear an alarming burden of the HIV epidemic, but are less likely to achieve adequate adherence and to have good clinical outcomes compared to their adult counterparts. ${ }^{115}$ Children and adolescents face complex barriers to access and adherence as the extent of their autonomy varies over the developmental course and they frequently rely on caregivers for treatment. Caregiver beliefs, ${ }^{116}$ education, ${ }^{117}$ and stress, ${ }^{118}$ as well as type of family structure, ${ }^{117}$ all influence pediatric access and adherence to ART. Vulnerable children, such as orphans, often face additional barriers to care. ${ }^{119}$ Disclosure of the child's HIV status, essential for long-term disease management, is associated with improved adherence, ${ }^{120}$ emotional health, ${ }^{121}$ and reduced conflict with caregivers, ${ }^{122}$ but disclosure rates vary and are generally low in resource-limited settings (Vreeman et al, unpublished data, 2012). Children, as adults, report experiencing various levels of HIV-related discrimination. ${ }^{123}$ Furthermore, issues that arise as children and adolescents transition from pediatric to adult care settings in LMIC have not been investigated sufficiently. ${ }^{124}$

Evidence for strategies to improve access and adherence to ART for children and adolescents is lacking. Two major reviews of interventions to improve adherence among children revealed limited support for home-based nursing care, peer support, and education sessions for caregivers and children to improve adherence; however, many studies suffered from weak methodologies, small sample sizes, and few were conducted in LMIC. ${ }^{125,126}$ Other reviews suggest that, along with child and caregiver-level interventions, improved ART regimens for children (palatability, pill burden/size) and relationships with providers can lead to better adherence to ART in children. ${ }^{127}$ Fewer studies evaluate access to treatment in children. An RCT in Swaziland showed the effectiveness of a school-based educational intervention in increasing HIV testing rates among students. ${ }^{128} \mathrm{~A}$ comprehensive care program in Kenya offering individual and group psychosocial support and treatment literacy for children and caregivers within a tailored, child-centered care model found improved clinical outcomes; however, individual components of the program could not be evaluated. ${ }^{129}$ Evaluation of a clinic-based DOT-ART program in Cambodia showed significantly improved CD4 counts $(P<0.001)$ after 18 months 
for orphaned children. ${ }^{130}$ Few studies examine the impact of disclosure on emotional health and adherence, ${ }^{131}$ but evaluation of one clinic-based disclosure program in Puerto Rico found improved rates of adherence after implementation ${ }^{132}$ and disclosure was linked to higher rates of adherence among children in Zambia. ${ }^{133}$

\section{Other high-risk populations}

Additional high-risk populations for HIV that need to be considered for targeted interventions include: individuals with comorbidities such as HIV-TB, substance abusers and individuals with mental disorders, men who have sex with men (MSM), sex workers, and prisoners. In 2010, there were 8 million new cases of TB worldwide with $13 \%$ of newly infected individuals also being HIV-positive. ${ }^{134}$ The vast majority of individuals living with HIV-TB, an estimated $82 \%$, reside in sub-Saharan Africa. ${ }^{134}$ The prevalence of substance abuse and psychiatric disorders is high among HIV-infected individuals, with many suffering from all three comorbidities. ${ }^{135}$ While substance abuse and mental disorders are associated with poorer adherence and treatment outcomes in resource-rich settings, ${ }^{136}$ less is known about prevalence and impact in LMIC. ${ }^{137}$ A recent meta-analysis of studies from LMIC found MSM were almost 20 times more likely to be infected with HIV than the general population, highlighting the risks faced by this population. ${ }^{138}$ In LMIC, prevalence of HIV among female sex workers was estimated at $11.8 \%(95 \%$ CI: $11.6-12.0)$ while among the 26 countries with the highest HIV burden, the overall prevalence jumped to $30.7 \%$ (95\% CI: $30.2-31.3) .{ }^{139}$ Finally, prisoners represent another high-risk population for HIV, but there is little data on HIV prevalence and treatment in LMIC. Small surveys in sub-Saharan Africa suggest high rates of HIV among prison populations, as high as $40 \%$ in a sample in South Africa. ${ }^{140}$

These populations face significant and, in some cases, unique barriers to HIV treatment, for example, criminalization in the case of homosexuality and lack of control over treatment for prisoners. Research to improve access and adherence among these populations is virtually nonexistent in LMIC. Interventions that fail to show effectiveness in general populations may prove efficacious among targeted populations. While the evidence from RCTs for DOT-ART is not convincing among the general population, targeted DOT-ART, such as for HIV-TB patients, may be more effective and has demonstrated feasibility and efficacy in small observational studies in resource-limited settings. ${ }^{141-143}$ Evidence from RCTs in resource-rich settings supports the use of DOT-ART for individuals with substance abuse disorders ${ }^{144-146}$ and prisoners. ${ }^{147}$ Depression, one of the most common mental disorders worldwide, ${ }^{148}$ has been shown to be associated with nonadherence to ART and poor engagement in care in all settings. ${ }^{149}$ Evidence from resource-rich settings suggests improved adherence and clinical outcomes with combined adherence and mental health counseling. ${ }^{150,151}$ No major studies have been conducted among MSM, sex workers, and prisoners, as most research and recommendations focus on prevention. ${ }^{152}$ A small observational study in London found a targeted multimedia campaign aimed at young gay men resulted in increased uptake in clinicbased HIV testing. ${ }^{153}$ Another small observational study in Vancouver found increased adherence and viral suppression with a peer-delivered intervention including support groups, patient advocates, outreach, and onsite nursing care among a group of female sex workers using illicit substances, although there was no comparison group. ${ }^{154}$

\section{Evaluating the evidence base}

While there is increasing data on barriers to treatment, a review of the scientific literature reveals limited evidence for strategies to improve access and adherence to ART in resource-limited settings. Interventions broadening HIV testing approaches, such as home-based, community, and mobile testing, show early evidence of increasing HIV testing and diagnosis. Observational and case studies generally support shifts in HIV care to improve retention through decentralization and integration of services, but only task-shifting to nurse- and peer health worker-based care is supported by RCTs. A larger evidence base is found for interventions directed at improving adherence. Adherence counseling and education interventions have been effective in some settings, and recent evidence supports a role for mobile phone technologies. RCTs to date do not provide sufficient evidence for using treatment supporters and DOT-ART to improve adherence among general populations; however, these strategies may be efficacious for certain populations such as children, HIV-TB patients, and substance abusers.

Studies assessing interventions directed at women, children, and adolescents and other special populations are scarce in LMIC. Provider-initiated inpatient testing has demonstrated feasibility and improved access for women in antenatal care settings, but few other interventions have been investigated adequately. This review also highlights the limited geographic variability among intervention studies to improve access and adherence, with the vast majority of the studies conducted in a few sub-Saharan African countries, including Kenya, South Africa, Uganda, and Zambia. While 
sub-Saharan Africa represents the epicenter of the HIV epidemic, studies investigating access and adherence are needed in other resource-constrained parts of the world where population and system-level contextual factors necessitate different approaches.

There are a number of critical weaknesses in studies evaluated for this review. A lack of standardization in evaluating linkage, retention, and adherence is an issue for both research and delivery of clinical care. While there are no common protocols to assess linkage, retention may be measured through gaps in care, clinic visits per interval of time, and number of missed visits. ${ }^{155}$ Further, individuals with HIV are a mobile population, moving through different stages of care, but also to different clinics and providers for care. ${ }^{156,157}$ Systems that monitor and link patients between points of care are essential for improving treatment and continuity of care. Adherence measures vary in different settings and common measures include self and proxy reports, pill counts, pharmacy refills, EDM, virologic markers (CD4 counts, viral loads), and blood draws for drug concentrations. No gold standard for measuring adherence has been proposed, ${ }^{158}$ and studies often use multiple measure to improve estimates. ${ }^{159}$ Long-term, routine monitoring of adherence is required to ensure optimal delivery of care, as adherence often decreases over time, ${ }^{160,161}$ but also to evaluate the effectiveness of interventions to improve adherence. Improving the methods that studies and care systems utilize to monitor linkage to and retention in care and adherence to ART will strengthen findings of intervention effectiveness.

\section{Directions for future research}

There are several critical gaps in the current evidence base that need to be addressed in future research. As HIV care systems transition through task shifting, decentralization, and integration and as more individuals need to be retained in treatment, monitoring of patients is critical to improving and expanding delivery of HIV care. Early rollout of health information systems, including electronic medical records, has been mostly positive in LMIC, ${ }^{162-166}$ but more research on technology-based information and surveillance systems and their potential to monitor and track patients throughout care is needed, along with how patient navigators and community outreach workers may supplement these systems. As HIV care systems horizontally integrate with other primary care services, there is an opportunity to implement various technologies into patient-based care that will improve not only HIV care, but strengthen local health care systems more broadly.
HIV-related stigma and discrimination remain major barriers to HIV treatment in LMIC, but this review found no major studies evaluating interventions to improve access and adherence through reducing stigma and discrimination against people living with HIV. A recent systematic review of interventions aimed at reducing HIV stigma evaluated 19 studies, of which nine were conducted in LMIC; however, studies suffered from various methodological weaknesses and no studies examined the association between reduced HIV stigma and health outcomes such as access and adherence to treatment. ${ }^{167}$ Very few studies investigating interventions to improve access and adherence include measures of stigma as secondary outcomes, although this review did find two such studies: a cohort study in Peru using community health workers delivering DOT-ART ${ }^{168}$ and an RCT in Kenya discussed previously assessing nurse-based DOT-ART. ${ }^{169}$ Further research on interventions aiming to reduce stigma, validation of stigma measures, and examining the association between intervention effects and health outcomes such as access and adherence are vital for addressing the significant challenges in HIV treatment due to stigma and discrimination. Issues in disclosure of HIV status, impacted by levels of perceived stigma, also deserve further investigation.

Social support networks have been identified in qualitative studies as important facilitators of HIV treatment, including adherence. ${ }^{170-172}$ Evidence for treatment supporters among qualitative and observational studies generally reveals more positive impacts on adherence and treatment outcomes than RCTs, ${ }^{173-178}$ and their findings warrant further investigation into the potential role for patient-nominated, family, friend or peer supporters in improving access and adherence. In sub-Saharan Africa, O'Laughlin et al suggest that treatment partners go beyond encouraging adherence to restoring access to social and community resources. ${ }^{179}$ In this way, treatment supports are sources of social capital and are important for obtaining treatment-sustaining resources such as money for transportation or food. ${ }^{180}$ As more patients in LMIC become ART experienced, "expert patients" from the community can likely play a crucial role in interventions to increase access and adherence as they have intimate knowledge of barriers and facilitators of care. ${ }^{181}$ This review only found two studies using persons living with HIV to deliver interventions. ${ }^{81,182}$ Increased involvement of this population in the design and implementation of interventions deserves investigation.

Simple, low-cost adherence tools such as pillboxes, medication planners, and calendars have not been investigated thoroughly in resource-limited settings. The use of pillboxes has shown efficacy in improving adherence in a US 
cohort, ${ }^{183}$ but has not been investigated in resource-limited settings. There may be variations in efficacy of such tools in settings where keeping medications secret is highly prized or where health literacy is more limited. Educational treatment calendars showed no impact on adherence or CD4 counts in an RCT in Tanzania comparing adherence counseling versus adherence counseling plus calendar. ${ }^{95}$ While electronic dose-timing alarms show positive effects in resource-rich settings, ${ }^{184,185}$ an RCT in Kenya found that the use of an alarm device did not significantly improve adherence. ${ }^{86} \mathrm{~A}$ small pretest-posttest intervention study reported on the delivery of a culturally sensitive educational videotape to improve adherence to ART in South Africa and showed increased knowledge of ART, side effects, and overall adherence strategies, although there was no control group. ${ }^{186}$ Combining low-cost adherence tools with counseling and education may offer benefits to adherence, but are not well studied in resource-limited settings. Another low-cost strategy to increase uptake in testing and utilization of services is mass media campaigns that can educate communities, raise awareness of availability of services, ${ }^{187}$ and may address issues of stigma. ${ }^{188}$ A Cochrane systematic review of mass media campaigns to increase uptake in HIV testing found that these interventions can increase testing rates, although no studies included in the review were from LMIC. ${ }^{189}$ This review found one study conducted in a resource-limited setting a retrospective cohort study in Kenya. ${ }^{190}$ Further research is needed on the efficacy of mass media campaigns and their potential to increase access and adherence.

Cost-effectiveness research is needed to evaluate the feasibility of implementing effective interventions in resource-limited settings and is just beginning to emerge. Overall, cost models have shown that high levels of adherence are associated with overall lower total health care costs in the US ${ }^{191}$ and in South Africa. ${ }^{192}$ There is limited research available on the cost-effectiveness in LMIC of various HIVtesting approaches, ${ }^{35,37,38}$ task-shifting to nurse-based care, ${ }^{67}$ and home-based ART care. ${ }^{193}$ There is a need to expand cost research in terms of overall reductions in health care costs associated with improved access and adherence to ART and the cost-effectiveness of efficacious strategies. With these data, programs can reliably estimate overall cost savings projections for efforts to improve access and adherence. Still, cost factors related to the price of ART remain outside the control of local HIV programs. Global partners, pharmaceutical companies, and national governments in LMIC need to continue to work together to create favorable global markets for ART whereby HIV programs in resource-limited settings gain increased access to the best available HIV medicines in line with WHO guidelines. ${ }^{194}$

Finally, new and creative directions in research are needed to address challenges in identifying effective strategies to improve access and adherence to ART in LMIC. RCTs are commonly considered the gold standard, but as research on HIV interventions moves forward, it is important to balance the strengths and weaknesses of RCTs against those of well-designed observational studies. For public health and sociobehavioral interventions, there is a place for observational studies, and complete reliance on RCTs is not always good practice. ${ }^{195}$ The use of qualitative data alongside RCTs is still relatively uncommon and not without methodological issues, ${ }^{196}$ but may be positioned to evaluate complex and multicomponent interventions. Beyond the scope of studies assessing intervention effectiveness is operational and implementation research. Operational research, using systematic research techniques to improve program operations and decision-making ${ }^{197}$ will be a critical endeavor for health care systems in LMIC to strengthen health infrastructure, human resources and capacity for local program design and evaluation. ${ }^{198}$ Implementation research, investigating how health systems implement and deliver evidence-based interventions, ${ }^{199}$ will be critical to guide governments and policy makers in replicating, adapting, and scaling up interventions.

\section{Conclusion}

Individuals living with HIV encounter many barriers to access and adherence to treatment. This nonsystematic review revealed few effective evidence-based strategies to guide clinicians, public health practitioners, and other health care providers. These findings make a compelling case for more data on improving delivery of ART in LMIC.

\section{Disclosure}

The authors report no conflicts of interest in this work. The views expressed in this article are those of the authors and do not necessarily represent the view of the Indiana University School of Medicine. The authors take full responsibility for the integrity of this review.

\section{References}

1. World Health Organization. Global HIV/AIDS Response: Epidemic update and health sector progress towards Universal Access - Progress Report 2011. Geneva: World Health Organization; 2011.

2. Life expectancy of individuals on combination antiretroviral therapy in high-income countries: a collaborative analysis of 14 cohort studies. Lancet. 2008;372(9635):293-299. 
3. Palella FJ Jr, Delaney KM, Moorman AC, et al. Declining morbidity and mortality among patients with advanced human immunodeficiency virus infection. HIV Outpatient Study Investigators. $N$ Engl J Med. 1998;338(13):853-860.

4. Simoni JM, Montgomery A, Martin E, New M, Demas PA, Rana S. Adherence to antiretroviral therapy for pediatric HIV infection: a qualitative systematic review with recommendations for research and clinical management. Pediatrics. 2007;119(6):e1371-e1383.

5. Vreeman RC, Wiehe SE, Pearce EC, Nyandiko WM. A systematic review of pediatric adherence to antiretroviral therapy in low- and middle-income countries. Pediatr Infect Dis J. 2008;27(8):686-691.

6. Mills EJ, Nachega JB, Buchan I, et al. Adherence to antiretroviral therapy in sub-Saharan Africa and North America: a meta-analysis. JAMA. 2006;296(6):679-690.

7. San-Andres FJ, Rubio R, Castilla J, et al. Incidence of acquired immunodeficiency syndrome-associated opportunistic diseases and the effect of treatment on a cohort of 1115 patients infected with human immunodeficiency virus, 1989-1997. Clin Infect Dis. 1 2003;36(9): 1177-1185.

8. Van Dyke RB, Lee S, Johnson GM, et al. Reported adherence as a determinant of response to highly active antiretroviral therapy in children who have human immunodeficiency virus infection. Pediatrics. 2002;109(4):e61.

9. Gross R, Yip B, Lo Re V 3rd, et al. A simple, dynamic measure of antiretroviral therapy adherence predicts failure to maintain HIV-1 suppression. J Infect Dis. 2006;194(8):1108-1114.

10. Lima VD, Harrigan R, Bangsberg DR, et al. The combined effect of modern highly active antiretroviral therapy regimens and adherence on mortality over time. J Acquir Immune Defic Syndr. 2009;50(5): 529-536.

11. Mullen J, Leech S, O'Shea S, et al. Antiretroviral drug resistance among HIV-1 infected children failing treatment. J Med Virol. 2002;68(3): 299-304.

12. Tam LW, Chui CK, Brumme CJ, et al. The relationship between resistance and adherence in drug-naive individuals initiating HAART is specific to individual drug classes. J Acquir Immune Defic Syndr. 2008;49(3):266-271.

13. Bangsberg DR, Acosta EP, Gupta R, et al. Adherence-resistance relationships for protease and non-nucleoside reverse transcriptase inhibitors explained by virological fitness. AIDS. 2006;20(2):223-231.

14. Crum NF, Riffenburgh RH, Wegner S, et al. Comparisons of causes of death and mortality rates among HIV-infected persons: analysis of the pre-, early, and late HAART (highly active antiretroviral therapy) eras. J Acquir Immune Defic Syndr. 2006;41(2):194-200.

15. Mills EJ, Nachega JB, Bangsberg DR, et al. Adherence to HAART: a systematic review of developed and developing nation patient-reported barriers and facilitators. PLoS Med. 2006;3(11):e438.

16. Posse M, Meheus F, van Asten H, van der Ven A, Baltussen R. Barriers to access to antiretroviral treatment in developing countries: a review. Trop Med Int Health. 2008;13(7):904-913.

17. Vreeman RC, Nyandiko WM, Blaschke TF. Adherence to antiretroviral therapy for adults and children in resource-limited settings. Reviews in Antiviral Therapy. 2009;2 Suppl:6-13.

18. Latkin CA, Knowlton AR. Micro-social structural approaches to HIV prevention: a social ecological perspective. AIDS Care. 2005; 17 Suppl 1: S102-S113.

19. McLeroy KR, Bibeau D, Steckler A, Glanz K. An ecological perspective on health promotion programs. Health Educ Q. 1988;15(4):351-377.

20. Kagee A, Remien RH, Berkman A, Hoffman S, Campos L, Swartz L. Structural barriers to ART adherence in Southern Africa: Challenges and potential ways forward. Glob Public Health. 2011;6(1):83-97.

21. Barton S. Which clinical studies provide the best evidence? The best RCT still trumps the best observational study. BMJ. 2000; 321(7256):255-256

22. Meldrum ML. A brief history of the randomized controlled trial. From oranges and lemons to the gold standard. Hematol Oncol Clin North Am. 2000;14(4):745-760, vii.
23. Nieburg P, Cannell T, Morrison J. Expanded HIV Testing: Critical Gateway to HIV Treatment and Prevention Requires Major Resources, Effective Protections. Washington, DC: Center for Strategic and International Studies; 2005.

24. Marum E, Taegtmeyer M, Chebet K. Scale-up of voluntary HIV counseling and testing in Kenya. JAMA. 2006;296(7):859-862.

25. HIV and AIDS Information [webpage on the Internet]. Alcorn K. South Africa to launch mass HIV testing drive in April, to test 15 million in one year. London: NAM Publications; 2010. Available from: http://www. aidsmap.com/South-Africa-to-launch-mass-HIV-testing-drive-in-Aprilto-test-15-million-in-one-year/page/1438260/. Accessed September 5, 2012 .

26. Bunnell R, Cherutich P. Universal HIV testing and counselling in Africa. Lancet. 2008;371(9631):2148-2150.

27. Cherutich P, Kaiser R, Galbraith J, et al. Lack of knowledge of HIV status a major barrier to HIV prevention, care and treatment efforts in Kenya: results from a nationally representative study. PLoS One. 2012;7(5):e36797.

28. Matovu JK, Makumbi FE. Expanding access to voluntary HIV counselling and testing in sub-Saharan Africa: alternative approaches for improving uptake, 2001-2007. Trop Med Int Health. 2007;12(11): 1315-1322.

29. WHO/UNAIDS. Guidance on Provider-Initiated HIV Testing and Counselling in Health Facilities. Geneva: World Health Organization; 2007.

30. Weiser SD, Heisler M, Leiter K, et al. Routine HIV testing in Botswana: a population-based study on attitudes, practices, and human rights concerns. PLoS Med. 2006;3(7):e261.

31. Hensen B, Baggaley R, Wong VJ, et al. Universal voluntary HIV testing in antenatal care settings: a review of the contribution of provider-initiated testing and counselling. Trop Med Int Health. 2012; 17(1):59-70.

32. Tumwesigye E, Wana G, Kasasa S, Muganzi E, Nuwaha F. High uptake of home-based, district-wide, HIV counseling and testing in Uganda. AIDS Patient Care STDS. 2010;24(11):735-741.

33. Wachira J, Kimaiyo S, Ndege S, Mamlin J, Braitstein P. What is the impact of home-based HIV counseling and testing on the clinical status of newly enrolled adults in a large HIV care program in Western Kenya? Clin Infect Dis. 2012;54(2):275-281.

34. Helleringer S, Kohler HP, Frimpong JA, Mkandawire J. Increasing uptake of HIV testing and counseling among the poorest in sub-Saharan countries through home-based service provision. J Acquir Immune Defic Syndr. 2009;51(2):185-193.

35. Grabbe KL, Menzies N, Taegtmeyer M, et al. Increasing access to HIV counseling and testing through mobile services in Kenya: strategies, utilization, and cost-effectiveness. J Acquir Immune Defic Syndr. 2010; 54(3):317-323.

36. Wolff B, Nyanzi B, Katongole G, Ssesanga D, Ruberantwari A, Whitworth J. Evaluation of a home-based voluntary counselling and testing intervention in rural Uganda. Health Policy Plan. 2005;20(2): 109-116.

37. Menzies N, Abang B, Wanyenze R, et al. The costs and effectiveness of four HIV counseling and testing strategies in Uganda. AIDS. 2009; 23(3):395-401.

38. Negin J, Wariero J, Mutuo P, Jan S, Pronyk P. Feasibility, acceptability and cost of home-based HIV testing in rural Kenya. Trop Med Int Health. 2009;14(8):849-855.

39. Thielman NM, Chu HY, Ostermann J, et al. Cost-effectiveness of free HIV voluntary counseling and testing through a community-based AIDS service organization in Northern Tanzania. Am J Public Health. 2006;96(1):114-119.

40. Wanyenze RK, Hahn JA, Liechty CA, et al. Linkage to HIV care and survival following inpatient HIV counseling and testing. AIDS Behav. 2011;15(4):751-760.

41. Fylkesnes K, Siziya S. A randomized trial on acceptability of voluntary HIV counselling and testing. Trop Med Int Health. 2004;9(5): $566-572$. 
42. Sweat M, Morin S, Celentano D, et al. Community-based intervention to increase HIV testing and case detection in people aged 16-32 years in Tanzania, Zimbabwe, and Thailand (NIMH Project Accept, HPTN 043): a randomised study. Lancet Infect Dis. 2011;11(7):525-532.

43. Khumalo-Sakutukwa G, Morin SF, Fritz K, et al. Project Accept (HPTN 043): a community-based intervention to reduce HIV incidence in populations at risk for HIV in sub-Saharan Africa and Thailand. J Acquir Immune Defic Syndr. 2008;49(4):422-431.

44. Corbett EL, Dauya E, Matambo R, et al. Uptake of workplace HIV counselling and testing: a cluster-randomised trial in Zimbabwe. PLoS Med. 2006;3(7):e238.

45. Lugada E, Levin J, Abang B, et al. Comparison of home and clinic-based HIV testing among household members of persons taking antiretroviral therapy in Uganda: results from a randomized trial. J Acquir Immune Defic Syndr. 2010;55(2):245-252.

46. Becker S, Mlay R, Schwandt HM, Lyamuya E. Comparing couples' and individual voluntary counseling and testing for HIV at antenatal clinics in Tanzania: a randomized trial. AIDS Behav. 2010;14(3): 558-566.

47. Ditekemena J, Matendo R, Koole O, et al. Male partner voluntary counselling and testing associated with the antenatal services in Kinshasa, Democratic Republic of Congo: a randomized controlled trial. Int $J$ STD AIDS. 2011;22(3):165-170.

48. Mohlala BK, Boily MC, Gregson S. The forgotten half of the equation: randomized controlled trial of a male invitation to attend couple voluntary counselling and testing. AIDS. 2011;25(12): 1535-1541.

49. Lawn SD, Harries AD, Anglaret X, Myer L, Wood R. Early mortality among adults accessing antiretroviral treatment programmes in subSaharan Africa. AIDS. 2008;22(15):1897-1908.

50. Fox MP, Sanne IM, Conradie F, et al. Initiating patients on antiretroviral therapy at CD4 cell counts above 200 cells/microl is associated with improved treatment outcomes in South Africa. AIDS. 2010;24(13): 2041-2050.

51. Kitahata MM, Gange SJ, Abraham AG, et al. Effect of early versus deferred antiretroviral therapy for HIV on survival. $N$ Engl J Med. 2009;360(18):1815-1826.

52. Bassett IV, Regan S, Chetty S, et al. Who starts antiretroviral therapy in Durban, South Africa? ... not everyone who should. AIDS. 2010; 24 Suppl 1:S37-S44.

53. Unge C, Johansson A, Zachariah R, Some D, Van Engelgem I, Ekstrom AM. Reasons for unsatisfactory acceptance of antiretroviral treatment in the urban Kibera slum, Kenya. AIDS Care. 2008;20(2): 146-149.

54. Kranzer K, Zeinecker J, Ginsberg P, et al. Linkage to HIV care and antiretroviral therapy in Cape Town, South Africa. PLoS One. 2010;5(11): e13801.

55. Brinkhof MW, Dabis F, Myer L, et al. Early loss of HIV-infected patients on potent antiretroviral therapy programmes in lower-income countries. Bull World Health Organ. 2008;86(7):559-567.

56. Cornell M, Grimsrud A, Fairall L, et al. Temporal changes in programme outcomes among adult patients initiating antiretroviral therapy across South Africa, 2002-2007. AIDS. 2010;24(14):2263-2270.

57. Nsigaye R, Wringe A, Roura M, et al. From HIV diagnosis to treatment: evaluation of a referral system to promote and monitor access to antiretroviral therapy in rural Tanzania. J Int AIDS Soc. 2009; 12(1):31

58. Hatcher AM, Turan JM, Leslie HH, et al. Predictors of linkage to care following community-based HIV counseling and testing in rural Kenya. AIDS Behav. 2012;16(5):1295-1307.

59. Mtapuri-Zinyowera S, Chideme M, Mangwanya D, et al. Evaluation of the PIMA point-of-care CD4 analyzer in VCT clinics in Zimbabwe. J Acquir Immune Defic Syndr. 2010;55(1):1-7.

60. Jani I, Sitoe N, Alfai E, et al. Point-of-care CD4 improve patient retention and time-to-initiation of ART in Mozambique. Paper presented at: XVIII International AIDS Conference; July 18-23, 2010; Vienna, Austria.
61. Faal M, Naidoo N, Makgamatha L, Venter F, Osih R. Effect of an immediate CD4 result during VCT on patient retention in ART. Paper presented at: XVIII International AIDS Conference; July 18-23, 2010; Vienna, Austria.

62. Larson B, Bistline K, Ndibongo B, et al. Rapid point-of-care CD4 testing at mobile HIV testing sites to increase linkage to care: an evaluation of a pilot program in South Africa. Paper presented at: 6th IAS Conference on HIV Pathogenesis, Treatment and Prevention; July 17-20, 2011; Rome, Italy.

63. Jani IV, Sitoe NE, Chongo PL, et al. Accurate CD4 T-cell enumeration and antiretroviral drug toxicity monitoring in primary healthcare clinics using point-of-care testing. AIDS. 2011;25(6):807-812.

64. Jani IV, Sitoe NE, Alfai ER, et al. Effect of point-of-care CD4 cell count tests on retention of patients and rates of antiretroviral therapy initiation in primary health clinics: an observational cohort study. Lancet. 2011;378(9802):1572-1579.

65. World Health Organization. The Treatment 2.0 Framework for Action: Catalysing the Next Phase of Treatment, Care and Support. Geneva: World Health Organization; 2011.

66. Brennan A, Long L, Maskew M, et al. Outcomes of stable HIV-positive patients down-referred from doctor-managed ART clinics to nursemanaged primary health clinics for monitoring and treatment. AIDS. 2011;25(16):2027-2036.

67. Long L, Brennan A, Fox MP, et al. Treatment outcomes and cost-effectiveness of shifting management of stable ART patients to nurses in South Africa: an observational cohort. PLoS Med. 2011;8(7): e1001055.

68. Morris MB, Chapula BT, Chi BH, et al. Use of task-shifting to rapidly scale-up HIV treatment services: experiences from Lusaka, Zambia. BMC Health Serv Res. 2009;9:5.

69. Shumbusho F, van Griensven J, Lowrance D, et al. Task shifting for scaleup of HIV care: evaluation of nurse-centered antiretroviral treatment at rural health centers in Rwanda. PLoS Med. 2009;6(10): e1000163.

70. Bemelmans M, van den Akker T, Ford N, et al. Providing universal access to antiretroviral therapy in Thyolo, Malawi through task shifting and decentralization of HIV/AIDS care. Trop Med Int Health. 2010;15(12):1413-1420.

71. Boyer S, Eboko F, Camara M, et al. Scaling up access to antiretroviral treatment for HIV infection: the impact of decentralization of healthcare delivery in Cameroon. AIDS. 2010;24 Suppl 1:S5-S15.

72. Searle C, Ramkissoon A, Govender T. Using a file audit to evaluate retention in care and patient outcomes in a programme to decentralise antiretroviral treatment to primary health care facilities in a high prevalence setting in KwaZulu-Natal, South Africa. Stud Health Technol Inform. 2010;160(Pt 1):476-480.

73. Pfeiffer J, Montoya P, Baptista AJ, et al. Integration of HIV/AIDS services into African primary health care: lessons learned for health system strengthening in Mozambique - a case study. J Int AIDS Soc. 2010;13:3.

74. Chan AK, Mateyu G, Jahn A, et al. Outcome assessment of decentralization of antiretroviral therapy provision in a rural district of Malawi using an integrated primary care model. Trop Med Int Health. 2010; 15 Suppl 1:90-97.

75. Decroo T, Panunzi I, das Dores C, et al. Lessons learned during down referral of antiretroviral treatment in Tete, Mozambique. J Int AIDS Soc. 2009;12:6.

76. Topp SM, Chipukuma JM, Giganti M, et al. Strengthening health systems at facility-level: feasibility of integrating antiretroviral therapy into primary health care services in lusaka, zambia. PLoS One. 2010;5(7): e11522.

77. Emenyonu N, Muyindike W, Habyarimana J, et al. Cash transfers to cover clinic transportation costs improve adherence and retention in care in a HIV treatment program in rural Uganda. Paper presented at: 17th Conference on Retroviruses and Opportunistic Infections; February 16-19, 2010; San Francisco, CA.

78. Matavu F, Wabwire D, Nakibuuka J, et al. Efficacy of using peer counselors and nurses to support adherence to HAART among HIV-1infected patients at the prevention of MTCT program, Mulago Hospital, Kampala, Uganda: a randomized non-inferiority intervention trial. Paper presented at: 18th Conference on Retroviruses and Opportunistic Infections; February 27-March 2, 2011; Boston, MA. 
79. Sanne I, Orrell C, Fox MP, et al. Nurse versus doctor management of HIV-infected patients receiving antiretroviral therapy (CIPRA-SA): a randomised non-inferiority trial. Lancet. 2010;376(9734):33-40.

80. Jaffar S, Amuron B, Foster S, et al. Rates of virological failure in patients treated in a home-based versus a facility-based HIV-care model in Jinja, southeast Uganda: a cluster-randomised equivalence trial. Lancet. 2009;374(9707):2080-2089.

81. Selke HM, Kimaiyo S, Sidle JE, et al. Task-shifting of antiretroviral delivery from health care workers to persons living with HIV/AIDS: clinical outcomes of a community-based program in Kenya. J Acquir Immune Defic Syndr. 2010;55(4):483-490.

82. Amico KR, Harman JJ, Johnson BT. Efficacy of antiretroviral therapy adherence interventions: a research synthesis of trials, 1996 to 2004. J Acquir Immune Defic Syndr. 2006;41(3):285-297.

83. Rueda S, Park-Wyllie LY, Bayoumi AM, et al. Patient support and education for promoting adherence to highly active antiretroviral therapy for HIV/AIDS. Cochrane Database Syst Rev. 2006;3:CD001442.

84. Simoni JM, Pearson CR, Pantalone DW, Marks G, Crepaz N. Efficacy of interventions in improving highly active antiretroviral therapy adherence and HIV-1 RNA viral load. A meta-analytic review of randomized controlled trials. J Acquir Immune Defic Syndr. 2006; 43 Suppl 1:S23-S35.

85. Busari O, Busari O, Oligbu G, Ashom D, Adeyemi A, Group HS. Novel structured teaching of HIV patients in resource-limited setting: effect of learning outcomes on adherence to HAART and immunological recovery. Paper presented at: 17th Conference of Retroviruses and Opportunistic Infections; February 16-19, 2010; San Francisco, CA.

86. Chung MH, Richardson BA, Tapia K, et al. A randomized controlled trial comparing the effects of counseling and alarm device on HAART adherence and virologic outcomes. PLoS Med. 2011;8(3): e1000422.

87. Sabin LL, DeSilva MB, Hamer DH, et al. Using electronic drug monitor feedback to improve adherence to antiretroviral therapy among HIVpositive patients in China. AIDS Behav. 2010;14(3):580-589.

88. Sampaio-Sa M, Page-Shafer K, Bangsberg DR, et al. 100\% adherence study: educational workshops vs video sessions to improve adherence among ART-naive patients in Salvador, Brazil. AIDS Behav. 2008; 12(4 Suppl):S54-S62.

89. Garcia R, Ponde M, Lima M, Souza AR, Stolze SM, Badaro R. Lack of effect of motivation on the adherence of HIV-positive/AIDS patients to antiretroviral treatment. Braz J Infect Dis. 2005;9(6):494-499.

90. Cantrell RA, Sinkala M, Megazinni K, et al. A pilot study of food supplementation to improve adherence to antiretroviral therapy among food-insecure adults in Lusaka, Zambia. J Acquir Immune Defic Syndr. 2008;49(2):190-195.

91. Serrano C, Laporte R, Ide M, et al. Family nutritional support improves survival, immune restoration and adherence in HIV patients receiving ART in developing country. Asia Pac J Clin Nutr. 2010;19(1): 68-75

92. Chang LW, Kagaayi J, Nakigozi G, et al. Effect of peer health workers on AIDS care in Rakai, Uganda: a cluster-randomized trial. PLoS One. 2010;5(6):e10923.

93. Arem H, Nakyanjo N, Kagaayi J, et al. Peer health workers and AIDS care in Rakai, Uganda: a mixed methods operations research evaluation of a cluster-randomized trial. AIDS Patient Care STDS. 2011;25(12):719-724.

94. Kunutsor S, Walley J, Katabira E, et al. Improving clinic attendance and adherence to antiretroviral therapy through a treatment supporter intervention in Uganda: a randomized controlled trial. AIDS Behav. 2011;15(8):1795-1802.

95. Mugusi F, Mugusi S, Bakari M, et al. Enhancing adherence to antiretroviral therapy at the HIV clinic in resource constrained countries; the Tanzanian experience. Trop Med Int Health. 2009;14(10): 1226-1232.

96. Pearson CR, Micek MA, Simoni JM, et al. Randomized control trial of peer-delivered, modified directly observed therapy for HAART in Mozambique. J Acquir Immune Defic Syndr. 2007;46(2):238-244.
97. Taiwo BO, Idoko JA, Welty LJ, et al. Assessing the viorologic and adherence benefits of patient-selected HIV treatment partners in a resource-limited setting. J Acquir Immune Defic Syndr. 2010;54(1): 85-92.

98. Nachega JB, Chaisson RE, Goliath R, et al. Randomized controlled trial of trained patient-nominated treatment supporters providing partial directly observed antiretroviral therapy. AIDS. 2010;24(9): 1273-1280.

99. Sarna A, Luchters S, Geibel S, et al. Short- and long-term efficacy of modified directly observed antiretroviral treatment in Mombasa, Kenya: a randomized trial. J Acquir Immune Defic Syndr. 2008;48(5): 611-619.

100. Lester RT, Ritvo P, Mills EJ, et al. Effects of a mobile phone short message service on antiretroviral treatment adherence in Kenya (WelTel Kenya1): a randomised trial. Lancet. 2010;376(9755):1838-1845.

101. Pop-Eleches C, Thirumurthy H, Habyarimana JP, et al. Mobile phone technologies improve adherence to antiretroviral treatment in a resource-limited setting: a randomized controlled trial of text message reminders. AIDS. 2011;25(6):825-834.

102. Uzma Q, Emmanuel F, Ather U, Zaman S. Efficacy of Interventions for Improving Antiretroviral Therapy Adherence in HIV/AIDS Cases at PIMS, Islamabad. J Int Assoc Physicians AIDS Care (Chic). 2011;10(6):373-383.

103. Chang LW, Kagaayi J, Arem H, et al. Impact of a mHealth intervention for peer health workers on AIDS care in rural Uganda: a mixed methods evaluation of a cluster-randomized trial. AIDS Behav. 2011;15(8):1776-1784.

104. Mbuagbaw L, Thabane L, Ongolo-Zogo P, et al. The Cameroon mobile phone SMS (CAMPS) trial: a protocol for a randomized controlled trial of mobile phone text messaging versus usual care for improving adherence to highly active anti-retroviral therapy. Trials. 2011;12:5.

105. De Costa A, Shet A, Kumarasamy N, et al. Design of a randomized trial to evaluate the influence of mobile phone reminders on adherence to first line antiretroviral treatment in South India - the HIVIND study protocol. BMC Med Res Methodol. 2010;10:25.

106. Kwalombota $M$, Shumba $C$. Influence of gender on access to antiretroviral therapy among African women. Paper presented at: XV International AIDS Conference; July 11-16, 2004; Bangkok, Thailand.

107. Shumba C, Kwalombota M. Accessibility of HIV therapy to women living with HIV/AIDS in Lusaka, Zambia. Paper presented at: The 2nd IAS Conference on HIV Pathogenesis and Treatment; July 13-16, 2003; Paris, France.

108. Murray LK, Semrau K, McCurley E, et al. Barriers to acceptance and adherence of antiretroviral therapy in urban Zambian women: a qualitative study. AIDS Care. 2009;21(1):78-86.

109. Morin SF, Khumalo-Sakutukwa G, Charlebois ED, et al. Removing barriers to knowing HIV status: same-day mobile HIV testing in Zimbabwe. J Acquir Immune Defic Syndr. 2006;41(2):218-224.

110. Msuya SE, Mbizvo E, Uriyo J, Stray-Pedersen B, Sam NE, Hussain A. Predictors of failure to return for HIV test results among pregnant women in Moshi, Tanzania. J Acquir Immune Defic Syndr. 2006;43(1):85-90.

111. Creek TL, Ntumy R, Seipone K, et al. Successful introduction of routine opt-out HIV testing in antenatal care in Botswana. J Acquir Immune Defic Syndr. 2007;45(1):102-107.

112. Homsy J, Kalamya JN, Obonyo J, et al. Routine intrapartum HIV counseling and testing for prevention of mother-to-child transmission of HIV in a rural Ugandan hospital. J Acquir Immune Defic Syndr. 2006;42(2):149-154.

113. Megazzini KM, Sinkala M, Vermund SH, et al. A cluster-randomized trial of enhanced labor ward-based PMTCT services to increase nevirapine coverage in Lusaka, Zambia. AIDS. 2010;24(3):447-455.

114. UNICEF. Children and AIDS: Fourth Stocktaking Report, 2009. United Nations Children's Fund, World Health Organization, The Joint United Nations Programme on HIV/AIDS, United Nations Population Fund; 2009. Available from: http://www.unicef.org/publications/files/ Children_and_AIDS_Fourth_Stocktaking_Report_EN_110609.pdf. Accessed October 2, 2012. 
115. Nachega JB, Hislop M, Nguyen H, et al. Antiretroviral therapy adherence, virologic and immunologic outcomes in adolescents compared with adults in southern Africa. J Acquir Immune Defic Syndr. 2009;51(1):65-71.

116. Fassinou P, Elenga N, Rouet F, et al. Highly active antiretroviral therapies among HIV-1-infected children in Abidjan, Cote d'Ivoire. AIDS. 24 2004;18(14):1905-1913.

117. Cupsa A, Gheonea C, Bulucea D, Dinescu S. Factors with a negative influence on compliance to antiretroviral therapies. Ann NY Acad Sci. 2000;918:351-354.

118. Mellins CA, Brackis-Cott E, Dolezal C, Abrams EJ. The role of psychosocial and family factors in adherence to antiretroviral treatment in human immunodeficiency virus-infected children. Pediatr Infect Dis J. 2004;23(11):1035-1041.

119. Vreeman RC, Wiehe SE, Ayaya SO, Musick BS, Nyandiko WM. Association of antiretroviral and clinic adherence with orphan status among HIV-infected children in Western Kenya. J Acquir Immune Defic Syndr. 2008;49(2):163-170.

120. Bikaako-Kajura W, Luyirika E, Purcell DW, et al. Disclosure of HIV status and adherence to daily drug regimens among HIV-infected children in Uganda. AIDS Behav. 2006;10(4 Suppl):S85-S93.

121. Mellins CA, Brackis-Cott E, Dolezal C, Richards A, Nicholas SW, Abrams EJ. Patterns of HIV status disclosure to perinatally HIVinfected children and subsequent mental health outcomes. Clin Child Psychol Psychiatry. 2002;7(1):101-114.

122. Fetzer BC, Mupenda B, Lusiama J, Kitetele F, Golin C, Behets F. Barriers to and facilitators of adherence to pediatric antiretroviral therapy in a sub-Saharan setting: insights from a qualitative study. AIDS Patient Care STDS. 2011;25(10):611-621.

123. Ayres JR, Paiva V, Franca I Jr, et al. Vulnerability, human rights, and comprehensive health care needs of young people living with HIV/ AIDS. Am J Public Health. 2006;96(6):1001-1006.

124. Dowshen N, D'Angelo L. Health care transition for youth living with HIV/AIDS. Pediatrics. 2011;128(4):762-771.

125. Bain-Brickley D, Butler LM, Kennedy GE, Rutherford GW. Interventions to improve adherence to antiretroviral therapy in children with HIV infection. Cochrane Database Syst Rev. 2011;12:CD009513.

126. Reisner SL, Mimiaga MJ, Skeer M, Perkovich B, Johnson CV, Safren SA. A review of HIV antiretroviral adherence and intervention studies among HIV-infected youth. Top HIV Med. 2009;17(1):14-25.

127. Shah CA. Adherence to high activity antiretrovial therapy (HAART) in pediatric patients infected with HIV: issues and interventions. Indian J Pediatr. 2007;74(1):55-60.

128. Burnett SM, Weaver MR, Mody-Pan PN, Thomas LA, Mar CM. Evaluation of an intervention to increase human immunodeficiency virus testing among youth in Manzini, Swaziland: a randomized control trial. J Adolesc Health. 2011;48(5):507-513.

129. Van Winghem J, Telfer B, Reid T, et al. Implementation of a comprehensive program including psycho-social and treatment literacy activities to improve adherence to HIV care and treatment for a pediatric population in Kenya. BMC Pediatr. 2008;8:52.

130. Myung P, Pugatch D, Brady MF, et al. Directly observed highly active antiretroviral therapy for HIV-infected children in Cambodia. Am J Public Health. 2007;97(6):974-977.

131. Wiener L, Mellins CA, Marhefka S, Battles HB. Disclosure of an HIV diagnosis to children: history, current research, and future directions. J Dev Behav Pediatr. 2007;28(2):155-166.

132. Blasini I, Chantry C, Cruz C, et al. Disclosure model for pediatric patients living with HIV in Puerto Rico: design, implementation, and evaluation. J Dev Behav Pediatr. 2004;25(3):181-189.

133. Haberer JE, Cook A, Walker AS, et al. Excellent adherence to antiretrovirals in HIV+ Zambian children is compromised by disrupted routine, HIV nondisclosure, and paradoxical income effects. PLoS One. 2011;6(4):e18505.

134. World Health Organization. Global Tuberculosis Control 2011. Geneva: World Health Organization; 2011. Available from: http:// www.who.int/tb/publications/global_report/2011/en/index.html. Accessed October 1, 2012.
135. Chander G, Himelhoch S, Moore RD. Substance abuse and psychiatric disorders in HIV-positive patients: epidemiology and impact on antiretroviral therapy. Drugs. 2006;66(6):769-789.

136. Mellins CA, Havens JF, McDonnell C, et al. Adherence to antiretroviral medications and medical care in HIV-infected adults diagnosed with mental and substance abuse disorders. AIDS Care. 2009;21(2): 168-177.

137. Myer L, Smit J, Roux LL, Parker S, Stein DJ, Seedat S. Common mental disorders among HIV-infected individuals in South Africa: prevalence, predictors, and validation of brief psychiatric rating scales. AIDS Patient Care STDS. 2008;22(2):147-158.

138. Baral S, Sifakis F, Cleghorn F, Beyrer C. Elevated risk for HIV infection among men who have sex with men in low- and middle-income countries 2000-2006: a systematic review. PLoS Med. 2007;4(12):e339.

139. Baral S, Beyrer C, Muessig K, et al. Burden of HIV among female sex workers in low-income and middle-income countries: a systematic review and meta-analysis. Lancet Infect Dis. 2012;12(7):538-549.

140. HIV and Prisons in sub-Saharan Africa: Opportunities for Action. United Nations Office on Drugs and Crime, Joint United Nations Programme on HIV/AIDS, World Bank; 2007. Available from: http:// www.unodc.org/documents/hiv-aids/Africa\%20HIV_Prison_Paper_ Oct-23-07-en.pdf. Accessed October 20, 2012.

141. Farmer P, Leandre F, Mukherjee J, Gupta R, Tarter L, Kim JY. Community-based treatment of advanced HIV disease: introducing DOT-HAART (directly observed therapy with highly active antiretroviral therapy). Bull World Health Organ. 2001;79(12):1145-1151.

142. Jack C, Lalloo U, Karim QA, et al. A pilot study of once-daily antiretroviral therapy integrated with tuberculosis directly observed therapy in a resource-limited setting. J Acquir Immune Defic Syndr. 2004;36(4):929-934.

143. Gandhi NR, Moll AP, Lalloo U, et al. Successful integration of tuberculosis and HIV treatment in rural South Africa: the Sizonq'oba study. J Acquir Immune Defic Syndr. 1 2009;50(1):37-43.

144. Altice FL, Maru DS, Bruce RD, Springer SA, Friedland GH Superiority of directly administered antiretroviral therapy over selfadministered therapy among HIV-infected drug users: a prospective, randomized, controlled trial. Clin Infect Dis. 2007;45(6):770-778.

145. Macalino GE, Hogan JW, Mitty JA, et al. A randomized clinical trial of community-based directly observed therapy as an adherence intervention for HAART among substance users. AIDS. 2007;21(11):1473-1477.

146. Maru DS, Bruce RD, Walton M, Springer SA, Altice FL. Persistence of virological benefits following directly administered antiretroviral therapy among drug users: results from a randomized controlled trial. J Acquir Immune Defic Syndr. 2009;50(2):176-181.

147. Grodensky G, Golin C, Sunil A, et al. Effect on antiretroviral adherence of directly observed therapy (DOT) versus 'keep own medicine' (KOM) among HIV-infected prisoners: The DOT-KOM Study. Paper presented at: 4th International Conference on HIV Treatment Adherence; April 5-7, 2009; Miami, FL.

148. Depression [webpage on the Internet]. Geneva: World Health Organization; 2012. Available from: http://www.who.int/mediacentre/ factsheets/fs369/en/index.html. Accessed October 3, 2012.

149. Gonzalez JS, Batchelder AW, Psaros C, Safren SA. Depression and HIV/AIDS treatment nonadherence: a review and meta-analysis. J Acquir Immune Defic Syndr. 2011;58(2):181-187.

150. Safren SA, O'Cleirigh C, Tan JY, et al. A randomized controlled trial of cognitive behavioral therapy for adherence and depression (CBT-AD) in HIV-infected individuals. Health Psychol. 2009;28(1):1-10.

151. Weiss SM, Tobin JN, Antoni M, et al. Enhancing the health of women living with HIV: the SMART/EST Women's Project. Int J Womens Health. 2011;3:63-77.

152. World Health Organization. Guidance for the Prevention and Treatment of HIV and Other Sexually Transmitted Infections among Men who Have Sex with Men and Transgender People. Geneva: World Health Organization; 2011. Available from: http://www.who.int/hiv/pub/ guidelines/msm_guidelines2011/en/. Accessed October 18, 2012. 
153. McOwan A, Gilleece Y, Chislett L, Mandalia S. Can targeted HIV testing campaigns alter health-seeking behaviour? AIDS Care. Jun 2002;14(3):385-390.

154. Deering KN, Shannon K, Sinclair H, Parsad D, Gilbert E, Tyndall MW. Piloting a peer-driven intervention model to increase access and adherence to antiretroviral therapy and HIV care among streetentrenched HIV-positive women in Vancouver. AIDS Patient Care STDS. 2009;23(8):603-609.

155. Mugavero MJ, Davila JA, Nevin CR, Giordano TP. From access to engagement: measuring retention in outpatient HIV clinical care. AIDS Patient Care STDS. 2010;24(10):607-613.

156. Geng EH, Nash D, Kambugu A, et al. Retention in care among HIVinfected patients in resource-limited settings: emerging insights and new directions. Curr HIV/AIDS Rep. 2010;7(4):234-244.

157. Yu JK, Tok TS, Tsai JJ, et al. What happens to patients on antiretroviral therapy who transfer out to another facility? PLoS One. 2008;3(4): e2065.

158. Osterberg L, Blaschke T. Adherence to medication. $N$ Engl J Med. 2005;353(5):487-497.

159. Chesney MA. The elusive gold standard. Future perspectives for HIV adherence assessment and intervention. JAcquir Immune Defic Syndr. 2006;43 Suppl 1:S149-S155.

160. Howard AA, Arnsten JH, Lo Y, et al. A prospective study of adherence and viral load in a large multi-center cohort of HIV-infected women. AIDS. 2002;16(16):2175-2182.

161. Mannheimer S, Friedland G, Matts J, Child C, Chesney M. The consistency of adherence to antiretroviral therapy predicts biologic outcomes for human immunodeficiency virus-infected persons in clinical trials. Clin Infect Dis. 2002;34(8):1115-1121.

162. Braitstein P, Einterz RM, Sidle JE, Kimaiyo S, Tierney W. "Talkin' about a revolution": How electronic health records can facilitate the scale-up of HIV care and treatment and catalyze primary care in resource-constrained settings. J Acquir Immune Defic Syndr. 2009; 52 Suppl 1:S54-S57.

163. Clifford GD, Blaya JA, Hall-Clifford R, Fraser HS. Medical information systems: a foundation for healthcare technologies in developing countries. Biomed Eng Online. 2008;7:18.

164. Tierney WM, Achieng M, Baker E, et al. Experience implementing electronic health records in three East African countries. Stud Health Technol Inform. 2010;160(Pt 1):371-375.

165. Alamo ST, Wagner GJ, Sunday P, et al. Electronic medical records and same day patient tracing improves clinic efficiency and adherence to appointments in a community based HIV/AIDS care program, in Uganda. AIDS Behav. 2012;16(2):368-374.

166. Forster M, Bailey C, Brinkhof MW, et al. Electronic medical record systems, data quality and loss to follow-up: survey of antiretroviral therapy programmes in resource-limited settings. Bull World Health Organ. 2008;86(12):939-947.

167. Sengupta S, Banks B, Jonas D, Miles MS, Smith GC. HIV interventions to reduce HIV/AIDS stigma: a systematic review. AIDS Behav. 2011; 15(6):1075-1087.

168. Munoz M, Finnegan K, Zeladita J, et al. Community-based DOTHAART accompaniment in an urban resource-poor setting. AIDS Behav. 2010;14(3):721-730.

169. Kaai S, Bullock S, Sarna A, et al. Perceived stigma among patients receiving antiretroviral treatment: a prospective randomised trial comparing an m-DOT strategy with standard-of-care in Kenya. Sahara J. 2010;7(2):62-70.

170. Cox LE. Social support, medication compliance and HIV/AIDS. Soc Work Health Care. 2002;35(1-2):425-460.

171. Simoni JM, Frick PA, Huang B. A longitudinal evaluation of a social support model of medication adherence among HIV-positive men and women on antiretroviral therapy. Health Psychol. 2006;25(1): 74-81.

172. Gonzalez JS, Penedo FJ, Antoni MH, et al. Social support, positive states of mind, and HIV treatment adherence in men and women living with HIV/AIDS. Health Psychol. 2004;23(4):413-418.
173. Birbeck GL, Chomba E, Kvalsund M, et al. Antiretroviral adherence in rural Zambia: the first year of treatment availability. Am J Trop Med Hyg. 2009;80(4):669-674.

174. Chi BH, Cantrell RA, Zulu I, et al. Adherence to first-line antiretroviral therapy affects non-virologic outcomes among patients on treatment for more than 12 months in Lusaka, Zambia. Int J Epidemiol. 2009; 38(3):746-756.

175. Nachega JB, Knowlton AR, Deluca A, et al. Treatment supporter to improve adherence to antiretroviral therapy in HIV-infected South African adults. A qualitative study. J Acquir Immune Defic Syndr. 2006;43 Suppl 1:S127-S133.

176. Ncama BP, McInerney PA, Bhengu BR, et al. Social support and medication adherence in HIV disease in KwaZulu-Natal, South Africa. Int J Nurs Stud. 2008;45(12):1757-1763.

177. Stubbs BA, Micek MA, Pfeiffer JT, Montoya P, Gloyd S. Treatment partners and adherence to HAART in Central Mozambique. AIDS Care. 2009;21(11):1412-1419.

178. Zuyderduin JR, Ehlers VJ, van der Wal DM. The impact of a buddy system on the self-care behaviours of women living with HIV/AIDS in Botswana. Health SA Gesondheid. 2008;13(4):4-15.

179. O'Laughlin KN, Wyatt MA, Kaaya S, Bangsberg DR, Ware NC. How treatment partners help: social analysis of an African adherence support intervention. AIDS Behav. 2012;16(5):1308-1315.

180. Ware NC, Idoko J, Kaaya S, et al. Explaining adherence success in sub-Saharan Africa: an ethnographic study. PLoS Med. 2009; 6(1):e11.

181. Decroo T, Van Damme W, Kegels G, Remartinez D, Rasschaert F. Are Expert Patients an Untapped Resource for ART Provision in Sub-Saharan Africa? AIDS Res Treat. 2012;2012:749718.

182. Decroo T, Telfer B, Biot M, et al. Distribution of antiretroviral treatment through self-forming groups of patients in Tete province, Mozambique. J Acquir Immune Defic Syndr. 2011;56(2):e39-e44.

183. Petersen ML, Wang Y, van der Laan MJ, Guzman D, Riley E, Bangsberg DR. Pillbox organizers are associated with improved adherence to HIV antiretroviral therapy and viral suppression: a marginal structural model analysis. Clin Infect Dis. 2007;45(7): 908-915.

184. Levy RW, Rayner CR, Fairley CK, et al. Multidisciplinary HIV adherence intervention: a randomized study. AIDS Patient Care STDS. 2004;18(12):728-735.

185. Safren SA, Hendriksen ES, Desousa N, Boswell SL, Mayer KH. Use of an on-line pager system to increase adherence to antiretroviral medications. AIDS Care. 2003;15(6):787-793.

186. Wong IY, Lawrence NV, Struthers H, McIntyre J, Friedland GH. Development and assessment of an innovative culturally sensitive educational videotape to improve adherence to highly active antiretroviral therapy in Soweto, South Africa. J Acquir Immune Defic Syndr. 2006;43 Supp1 1:S142-S148.

187. Grilli R, Ramsay C, Minozzi S. Mass media interventions: effects on health services utilisation. Cochrane Database Syst Rev. 2002;1: CD000389.

188. Nanda S, Pramanik. Media exposure, gender stereotype and contextual stigma perceptions about HIV and AIDS. Evidences from Gujarat, India. Journal of Health Management. 2010;12(4):461-481.

189. Vidanapathirana J, Abramson MJ, Forbes A, Fairley C. Mass media interventions for promoting HIV testing: Cochrane systematic review. Int J Epidemiol. 2006;35(2):233-234.

190. Marum E, Morgan G, Hightower A, Ngare C, Taegtmeyer M. Using mass media campaigns to promote voluntary counseling and HIVtesting services in Kenya. AIDS. 1 2008;22(15):2019-2024.

191. Freedberg KA, Hirschhorn LR, Schackman BR, et al. Cost-effectiveness of an intervention to improve adherence to antiretroviral therapy in HIV-infected patients. J Acquir Immune Defic Syndr. 2006;43 Suppl 1: S113-S118.

192. Nachega JB, Leisegang R, Bishai D, et al. Association of antiretroviral therapy adherence and health care costs. Ann Intern Med. 2010;152(1): $18-25$ 
193. Marseille E, Kahn JG, Pitter C, et al. The cost effectiveness of homebased provision of antiretroviral therapy in rural Uganda. Appl Health Econ Health Policy. 2009;7(4):229-243.

194. Waning B, Kyle M, Diedrichsen E, et al. Intervening in global markets to improve access to HIV/AIDS treatment: an analysis of international policies and the dynamics of global antiretroviral medicines markets. Global Health. 2010;6:9.

195. Grossman J, Mackenzie FJ. The randomized controlled trial: gold standard, or merely standard? Perspect Biol Med. 2005;48(4): $516-534$

196. Lewin S, Glenton C, Oxman AD. Use of qualitative methods alongside randomised controlled trials of complex healthcare interventions: methodological study. BMJ. 2009;339:b3496.

197. World Health Organization. Expanding Capacity for Operations Research in Reproductive Health: Summary Report of a Consultative Meeting, December 10-12, 2001. Geneva: World Health Organization; 2003. Available from: http://www.who.int/ reproductivehealth/publications/general/RHR_02_18/en/index.html. Accessed October 23, 2012.

198. Zachariah R, Harries AD, Ishikawa N, et al. Operational research in low-income countries: what, why, and how? Lancet Infect Dis. 2009; 9(11):711-717.

199. Sanders D, Haines A. Implementation research is needed to achieve international health goals. PLoS Med. 2006;3(6):e186.

200. Alwano-Edyegu M, Marum E. Knowledge is Power: Voluntary HIV Counselling and Testing in Uganda. Geneva: UNAIDS; 1999.

201. Dimbungu R, Nduhura D, Hadjipateras A, Bajenja E. Factors inhibiting access to ARVs treatment and PMTCT services: an analysis of the experience in North West Botswana. Paper presented at: XV International AIDS Conference; July 11-16, 2004; Bangkok, Thailand.

202. Grant E, Patching A, Gorman D, et al. Cultural factors influencing access to and adherence with antiretroviral therapy (ART) in an urban Zambian community. Paper presented at: XVI International AIDS Conference 2006; Aug 13-18; Toronto, Canada.

203. Lertpiriyasuwat C, Yachompoo C, Yuktanon P, et al. Access to antiretroviral drugs in northern Thailand: perspectives on persons living with HIV/AIDS. Paper presented at: XV International AIDS Conference; July 11-16, 2004; Bangkok, Thailand.

204. Ramchandani SR, Mehta SH, Saple DG, et al. Knowledge, attitudes, and practices of antiretroviral therapy among HIV-infected adults attending private and public clinics in India. AIDS Patient Care STDS. 2007;21(2):129-142.

205. Brigido LF, Rodrigues R, Casseb J, et al. Impact of adherence to antiretroviral therapy in HIV-1-infected patients at a university public service in Brazil. AIDS Patient Care STDS. 2001;15(11):587-593.

206. Hofer CB, Schechter M, Harrison LH. Effectiveness of antiretroviral therapy among patients who attend public HIV clinics in Rio de Janeiro, Brazil. J Acquir Immune Defic Syndr. 2004;36(4):967-971.

207. Sanjobo N, Frich JC, Fretheim A. Barriers and facilitators to patients' adherence to antiretroviral treatment in Zambia: a qualitative study. Sahara J. 2008;5(3):136-143.

208. Byakika-Tusiime J, Oyugi JH, Tumwikirize WA, Katabira ET, Mugyenyi PN, Bangsberg DR. Adherence to HIV antiretroviral therapy in HIV+ Ugandan patients purchasing therapy. Int $J$ STD AIDS. 2005;16(1):38-41.

209. da Silveira VL, Drachler Mde L, Leite JC, Pinheiro CA. Characteristics of HIV antiretroviral regimen and treatment adherence. Braz J Infect Dis. 2003;7(3):194-201.

210. Monreal MT, da Cunha RV, Trinca LA. Compliance to antiretroviral medication as reported by AIDS patients assisted at the University Hospital of the Federal University of Mato Grosso do Sul. Braz J Infect Dis. 2002;6(1):8-14.

211. Nachega JB, Stein DM, Lehman DA, et al. Adherence to antiretroviral therapy in HIV-infected adults in Soweto, South Africa. AIDS Res Hum Retroviruses. 2004;20(10):1053-1056.

212. Starks H, Simoni J, Zhao H, et al. Conceptualizing antiretroviral adherence in Beijing, China. AIDS Care. 2008;20(6):607-614.
213. Weiser S, Wolfe W, Bangsberg D, et al. Barriers to antiretroviral adherence for patients living with HIV infection and AIDS in Botswana. J Acquir Immune Defic Syndr. 2003;34(3):281-288.

214. Molassiotis A, Nahas-Lopez V, Chung WY, Lam SW, Li CK, Lau TF. Factors associated with adherence to antiretroviral medication in HIV-infected patients. Int J STD AIDS. 2002;13(5):301-310.

215. van Oosterhout JJ, Bodasing N, Kumwenda JJ, et al. Evaluation of antiretroviral therapy results in a resource-poor setting in Blantyre, Malawi. Trop Med Int Health. 2005;10(5):464-470.

216. Grant E, Logie D, Masura M, Gorman D, Murray SA. Factors facilitating and challenging access and adherence to antiretroviral therapy in a township in the Zambian Copperbelt: a qualitative study. AIDS Care. 2008;20(10):1155-1160.

217. Pinheiro CA, de-Carvalho-Leite JC, Drachler ML, Silveira VL. Factors associated with adherence to antiretroviral therapy in HIV/AIDS patients: a cross-sectional study in Southern Brazil. Braz J Med Biol Res. 2002;35(10):1173-1181.

218. Eholie SP, Tanon A, Polneau S, et al. Field adherence to highly active antiretroviral therapy in HIV-infected adults in Abidjan, Cote d'Ivoire. J Acquir Immune Defic Syndr. 2007;45(3):355-358.

219. Stout BD, Leon MP, Niccolai LM. Nonadherence to antiretroviral therapy in HIV-positive patients in Costa Rica. AIDS Patient Care STDS. 2004;18(5):297-304.

220. Sabin LL, Desilva MB, Hamer DH, et al. Barriers to adherence to antiretroviral medications among patients living with HIV in southern China: a qualitative study. AIDS Care. 2008;20(10): 1242-1250.

221. Jaquet A, Ekouevi DK, Bashi J, et al. Alcohol use and non-adherence to antiretroviral therapy in $\mathrm{HIV}$-infected patients in West Africa. Addiction. 2010;105(8):1416-1421.

222. Powell-Cope GM, White J, Henkelman EJ, Turner BJ. Qualitative and quantitative assessments of HAART adherence of substance-abusing women. AIDS Care. 2003;15(2):239-249.

223. Murphy DA, Roberts KJ, Martin DJ, Marelich W, Hoffman D. Barriers to antiretroviral adherence among HIV-infected adults. AIDS Patient Care STDS. 2000;14(1):47-58.

224. Proctor VE, Tesfa A, Tompkins DC. Barriers to adherence to highly active antiretroviral therapy as expressed by people living with HIV/ AIDS. AIDS Patient Care STDS. 1999;13(9):535-544.

225. Misener TR, Sowell RL. HIV-infected women's decisions to take antiretrovirals. West J Nurs Res. 1998;20(4):431-447.

226. Richter DL, Sowell RL, Pluto DM. Attitudes toward antiretroviral therapy among African American women. Am J Health Behav. 2002; 26(1):25-33.

227. Nozaki I, Kuriyama M, Manyepa P, Zyambo MK, Kakimoto K, Barnighausen T. False Beliefs About ART Effectiveness, Side Effects and the Consequences of Non-retention and Non-adherence Among ART Patients in Livingstone, Zambia. AIDS Behav. Epub June 20, 2012.

228. Peltzer K, Preez NF, Ramlagan S, Fomundam H. Use of traditional complementary and alternative medicine for HIV patients in KwaZuluNatal, South Africa. BMC Public Health. 2008;8:255.

229. Dahab M, Charalambous S, Hamilton R, et al. "That is why I stopped the ART": patients' and providers' perspectives on barriers to and enablers of HIV treatment adherence in a South African workplace programme. BMC Public Health. 2008;8:63.

230. Mshana GH, Wamoyi J, Busza J, et al. Barriers to accessing antiretroviral therapy in Kisesa, Tanzania: a qualitative study of early rural referrals to the national program. AIDS Patient Care STDS. 2006; 20(9):649-657.

231. Fox MP, Mazimba A, Seidenberg P, Crooks D, Sikateyo B, Rosen S. Barriers to initiation of antiretroviral treatment in rural and urban areas of Zambia: a cross-sectional study of cost, stigma, and perceptions about ART. J Int AIDS Soc. 2010;13:8.

232. Khonyongwa L. HIV/AIDS treatment access study, a premise for policy and advocacy in Malawi. Paper presented at: XV International AIDS Conference; July 11-16, 2004; Bangkok, Thailand. 
233. Weiser SD, Tuller DM, Frongillo EA, Senkungu J, Mukiibi N, Bangsberg DR. Food insecurity as a barrier to sustained antiretroviral therapy adherence in Uganda. PLoS One. 2010;5(4):e10340.

234. Hardon AP, Akurut D, Comoro C, et al. Hunger, waiting time and transport costs: time to confront challenges to ART adherence in Africa. AIDS Care. 2007;19(5):658-665.

235. Ammassari A, Trotta MP, Murri R, et al. Correlates and predictors of adherence to highly active antiretroviral therapy: overview of published literature. J Acquir Immune Defic Syndr. 2002;31 Suppl 3: S123-S127.

236. Chakrapani V, Newman PA, Shunmugam M, Kurian AK, Dubrow R. Barriers to free antiretroviral treatment access for female sex workers in Chennai, India. AIDS Patient Care STDS. 2009;23(11): 973-980.

237. Alker A, Delvaux T, Mbuyi N, Ryder R. Barriers to treatment of women in Kinshasa, DRC. Paper presented at: XV International AIDS Conference; July 11-16, 2004; Bangkok, Thailand.

238. Gamanya G. A study on how stigma and discrimination worsens the health of women with HIV/AIDS. Paper presented at: 3rd IAS Conference on HIV Pathogenesis and Treatment; July 25-28, 2005; Rio de Janeiro, Brazil.

239. Nabukeera-Barungi N, Kalyesubula I, Kekitiinwa A, Byakika-Tusiime J, Musoke P. Adherence to antiretroviral therapy in children attending Mulago Hospital, Kampala. Ann Trop Paediatr. 2007;27(2): $123-131$.

240. Talam NC, Gatongi P, Rotich J, Kimaiyo S. Factors affecting antiretroviral drug adherence among HIV/AIDS adult patients attending HIV/AIDS clinic at Moi Teaching and Referral Hospital, Eldoret, Kenya. East Afr J Public Health. 2008;5(2):74-78.

241. Watt MH, Maman S, Earp JA, et al. "It's all the time in my mind": facilitators of adherence to antiretroviral therapy in a Tanzanian setting. Soc Sci Med. 2009;68(10):1793-1800.

242. Nachega JB, Morroni C, Zuniga JM, et al. HIV Treatment Adherence, Patient Health Literacy, and Health Care Provider-Patient Communication: Results from the 2010 AIDS Treatment for Life International Survey. J Int Assoc Physicians AIDS Care (Chic). 2012;11(2): 128-133.

243. Campero L, Herrera C, Kendall T, Caballero M. Bridging the gap between antiretroviral access and adherence in Mexico. Qual Health Res. 2007;17(5):599-611.

244. Moon S, Van Leemput L, Durier N, et al. Out-of-pocket costs of AIDS care in China: are free antiretroviral drugs enough? AIDS Care. 2008;20(8):984-994.

245. Riyarto S, Hidayat B, Johns B, et al. The financial burden of HIV care, including antiretroviral therapy, on patients in three sites in Indonesia. Health Policy Plan. 2010;25(4):272-282.

246. Geng EH, Bangsberg DR, Musinguzi N, et al. Understanding reasons for and outcomes of patients lost to follow-up in antiretroviral therapy programs in Africa through a sampling-based approach. J Acquir Immune Defic Syndr. 2010;53(3):405-411.

247. Joshi K, Jhanwar S, Mathur A, et al. Barriers in adherence of ART (anti retroviral treatment): an experience of ART Centre of Western Rajasthan, Indian. 17th International AIDS Conference; August 3-8, 2008; Mexico City, Mexico.

248. Ochieng-Ooko V, Ochieng D, Sidle JE, et al. Influence of gender on loss to follow-up in a large HIV treatment programme in western Kenya. Bull World Health Organ. 2010;88(9):681-688.

249. Raguenaud M, Isaakidis P, Vonthanak S, et al. Good ART patient outcomes and surivival achieved in a six-year HIV/AIDS program in Cambodia. Paper presented at: 5th IAS Conference on HIV Pathogenesis, Treatment, and Prevention; July 19-22, 2009; Cape Town, South Africa.

250. Yu JK, Chen SC, Wang KY, et al. True outcomes for patients on antiretroviral therapy who are "lost to follow-up" in Malawi. Bull World Health Organ. 2007;85(7):550-554.
251. Tuller DM, Bangsberg DR, Senkungu J, Ware NC, Emenyonu N, Weiser SD. Transportation costs impede sustained adherence and access to HAART in a clinic population in southwestern Uganda: a qualitative study. AIDS Behav. 2010;14(4):778-784.

252. Ojikutu B, Jack C, Ramjee G. Provision of antiretroviral therapy in South Africa: unique challenges and remaining obstacles. J Infect Dis. 2007;196 Suppl 3:S523-S527.

253. Sarna A, Kellerman S. Access to antiretroviral therapy for adults and children with HIV infection in developing countries: Horizons studies, 2002-2008. Public Health Rep. 2010;125(2):305-315.

254. Sarna A, Pujari S, Sengar AK, Garg R, Gupta I, Dam J. Adherence to antiretroviral therapy and its determinants amongst HIV patients in India. Indian J Med Res. 2008;127(1):28-36.

255. Sued O, Schreiber C, Giron N, Ghidinelli M. HIV drug and supply stockouts in Latin America. Lancet Infect Dis. 2011;11(11):810-811.

256. Wouters E, Heunis C, van Rensburg D, Meulemans H. Patient satisfaction with antiretroviral services at primary health-care facilities in the Free State, South Africa - a two-year study using four waves of cross-sectional data. BMC Health Serv Res. 2008;8:210.

257. Gichoya-Wawira J, Ernest M. Laboratory-related barriers to access of anti-retroviral therapy (ART) in Kenya. Paper presented at: 3rd IAS Conference on HIV Pathogenesis and Treatment; July 25-28, 2005; Rio de Janeiro, Brazil.

258. Posse M, Baltussen R. Barriers to access to antiretroviral treatment in Mozambique, as perceived by patients and health workers in urban and rural settings. AIDS Patient Care STDS. 2009;23(10): 867-875.

259. Odhiambo J, Kizito W, Njoroge A, et al. Provider-initiated HIV testing and counselling for TB patients and suspects in Nairobi, Kenya. Int $J$ Tuberc Lung Dis. 2008;12(3 Suppl 1):63-68.

260. Kohler PK, Chung MH, McGrath CJ, Benki-Nugent SF, Thiga JW, John-Stewart GC. Implementation of free cotrimoxazole prophylaxis improves clinic retention among antiretroviral therapy-ineligible clients in Kenya. Aids. 24 2011;25(13):1657-1661.

261. Mukherjee JS, Ivers L, Leandre F, Farmer P, Behforouz H. Antiretroviral therapy in resource-poor settings. Decreasing barriers to access and promoting adherence. J Acquir Immune Defic Syndr. 2006;43 Suppl 1:S123-S126.

262. Ivers LC, Chang Y, Gregory Jerome J, Freedberg KA. Food assistance is associated with improved body mass index, food security and attendance at clinic in an HIV program in central Haiti: a prospective observational cohort study. AIDS Res Ther. 2010;7:33.

263. Abrams EJ, Myer L, Rosenfield A, El-Sadr WM. Prevention of motherto-child transmission services as a gateway to family-based human immunodeficiency virus care and treatment in resource-limited settings: rationale and international experiences. Am J Obstet Gynecol. 2007;197(Suppl 3):S101-S106.

264. Reddi A, Leeper SC, Grobler AC, et al. Preliminary outcomes of a paediatric highly active antiretroviral therapy cohort from KwaZuluNatal, South Africa. BMC Pediatr. 2007;7:13.

265. Kipp W, Konde-Lule J, Saunders LD, et al. Results of a communitybased antiretroviral treatment program for HIV-1 infection in Western Uganda. Curr HIV Res. 2010;8(2):179-185.

266. Kunutsor S, Walley J, Muchuro S, et al. Improving adherence to antiretroviral therapy in sub-Saharan African HIV-positive populations: an enhanced adherence package. AIDS Care. 2012;24(10):1308-1315.

267. Rodrigues R, Shet A, Antony J, et al. Supporting adherence to antiretroviral therapy with mobile phone reminders: results from a cohort in South India. PLoS One. 2012;7(8):e40723.

268. Sidney K, Antony J, Rodrigues R, et al. Supporting patient adherence to antiretrovirals using mobile phone reminders: patient responses from South India. AIDS Care. 2012;24(5):612-617. 
HIV/AIDS - Research and Palliative Care

Dovepress

\section{Publish your work in this journal}

HIV/AIDS - Research and Palliative Care is an international, peerreviewed open-access journal focusing on advances in research in HIV, its clinical progression and management options including antivira treatment, palliative care and public healthcare policies to control viral spread. The journal welcomes original research, basic science, clinical \& epidemiological studies, reviews \& evaluations, expert opinion \& commentary, case reports \& extended reports. The manuscript management system is completely online and includes a very quick and fair peer-review system. Visit http://www.dovepress.com/ testimonials.php to read real quotes from published authors.

Submit your manuscript here: http://www.dovepress.com/hivaids---research-and-palliative-care-journal 